\title{
48. EVIDENCE FOR LATE EOCENE TO EARLY OLIGOCENE ANTARCTIC GLACIATION AND OBSERVATIONS ON LATE NEOGENE GLACIAL HISTORY OF ANTARCTICA: RESULTS FROM LEG 1191
}

\author{
John Barron, ${ }^{2}$ Birger Larsen, ${ }^{3}$ and Jack G. Baldauf ${ }^{4}$
}

\begin{abstract}
Although scientific evidence prior to that from ODP Leg 119 indicates the presence of an ice sheet on East Antarctica by at least the earliest Oligocene, the question as to the size and stability of that initial ice sheet is still contested. Current hypotheses include (1) the presence of a small ice sheet in the earliest Oligocene with stepwise growth during the Neogene, (2) the presence of a continental-sized ice sheet in the late middle Eocene with no major evidence of subsequent deglaciation, and (3) the presence of glacial ice in the earliest Oligocene with a major ice sheet during the midOligocene, followed by growth and decay of several ice sheets with characteristics similar to the temperate ice sheets of the Pleistocene of North America but with changes over a longer time scale (millions of years vs. 100,000 yr).

Principal results from Leg 119 suggest the presence of significant late middle and late Eocene glaciation in East Antarctica and the presence of a continental-size ice sheet in East Antarctica during the earliest Oligocene. Although the Leg 119 results provide only glimpses of the Neogene glacial history of East Antarctica, they do provide evidence of fluctuations in the extent of the ice sheet and the waxing and waning of glaciers across the Prydz Bay shelf during the later part of the late Miocene and Pliocene.
\end{abstract}

\section{INTRODUCTION}

Throughout the study of the history of Cenozoic Antarctic glaciation, questions have focused on the age of formation of the Antarctic ice sheet and its size and stability through time. To date, the majority of evidence used to infer the Cenozoic glacial history of Antarctica has come from sediment records obtained from deep-sea cores collected in seas adjacent to Antarctica rather than from the Antarctic continent itself. Proxy signals such as ice-rated detritus, oxygen isotopes of both benthic and planktonic foraminifers, biogenic sediment type (carbonate vs. siliceous), clay minerals, microfossil assemblages, and the presence or absence of pollen as an indication of vegetation on Antarctica have been utilized to infer Antarctic glacial history (Kennett, 1977; Webb, 1990; Denton et al., in press; Kennett and Barker, 1990). In addition, the Haq et al. (1987) eustatic sealevel curve requires a global control for third-order changes in sea level. Variation in the size of the East Antarctic ice sheet would seem to be the most plausible source for late (or latest) Cenozoic fluctuations in global sea level prior to the initiation of Northern Hemisphere glaciation at $\sim 2.5 \mathrm{Ma}$ (Vail et al., 1977; Vail and Hardenbol, 1979; Matthews and Poore, 1980; Loutit and Kennett, 1981).

Ocean Drilling Program (ODP) Leg 119 (December 1987February 1988) was the third of four ODP legs $(113,114,119$, 120) designed to study the Cenozoic glacial history of East Antarctica and the oceanographic and sedimentologic response to climate and tectonic changes. Leg 119 completed 22 holes at 11 sites in the Indian sector of the Southern Ocean on the Kerguelen Plateau (Sites 736-738, 744-746) and in Prydz Bay, East Antarctica (Sites 739-743; see Table 1 and Figs. 1 and 2). Gla-

\footnotetext{
${ }^{1}$ Barron, J., Larsen, B., et al., 1991. Proc. ODP, Sci. Results, 119: College Station, TX (Ocean Drilling Program).

2 U.S. Geological Survey, MS 915, 345 Middlefield Road, Menlo Park, CA 94025 , U.S.A.

${ }^{3}$ Geological Survey of Denmark, Thoravej 8, DK 2400 Copenhagen, Denmark.

${ }^{4}$ Ocean Drilling Program, 1000 Discovery Drive, College Station, TX 77845 9547, U.S.A.
}

cial sediments recovered from Prydz Bay Sites 739 and 742 provide direct evidence of the late Paleogene and late Neogene glacial history of East Antarctica, as opposed to the deep-sea proxy records obtained on ODP Legs 113,114, and 120. Consequently, it is appropriate in this synthesis to focus on the evidence currently available to discuss the glacial history of East Antarctica. ODP Leg 119 drilling results provide the opportunity to address specifically, the timing and oceanographic response to (1) the late Paleogene initiation of major glaciation in East Antarctica, as well as (2) the late Neogene glacial history of East Antarctica and its effect on ocean circulation and sedimentation in the Kerguelen Plateau region.

\section{PREVIOUS EVIDENCE OF INITIATION OF CENOZOIC ANTARCTIC GLACIATION}

\section{Isotopes}

The age of onset of Cenozoic Antarctic glaciation has been the source of considerable debate in recent years mostly because of differing interpretations of the deep-sea oxygen isotope record (Matthews and Poore, 1980; Wise et al., 1985; Miller et al., 1987). Shackleton and Kennett (1975) compiled a Cenozoic oxygen isotope record of benthic and planktonic foraminifers from Deep Sea Drilling Project (DSDP) Sites 277, 279, and 281 in the southwest Pacific (about $48^{\circ}-52^{\circ} \mathrm{S}$ ) and proposed that the earliest Oligocene was the first time that the mean annual temperature in high southern latitudes was near freezing, which allowed glaciers in Antarctica to descend to sea level and resulted in sea-ice production. They argued that if an ice sheet was present in the earliest Oligocene, it could not have been more than a small fraction of its modern size.

Wise et al. (1985) argued that Shackleton and Kennett's (1975) temperature estimates for early Oligocene bottom waters were too cold, implying that part of the $\delta^{18} \mathrm{O}$ increase had to be ice volume. They suggested any early Oligocene ice sheet on Antarctica probably did not reach the sea, so that evidence for such an early Oligocene ice sheet would be difficult to see in deep sea proxy records. They went on to argue that any Oligocene ice sheet was probably destroyed in the early Miocene, and 
Table 1. Location of holes drilled on Leg 119.

\begin{tabular}{lcr}
\hline & & \\
Hole & $\begin{array}{c}\text { Latitude }\left({ }^{\circ} \mathrm{S}\right) / \\
\text { Longitude }\left({ }^{\circ} \mathrm{E}\right)\end{array}$ & $\begin{array}{r}\text { Water } \\
\text { depth } \\
(\mathrm{m})\end{array}$ \\
\hline $736 \mathrm{~A}$ & $49.40 / 71.66$ & 629.0 \\
$736 \mathrm{~B}$ & $49.40 / 71.66$ & 628.1 \\
$736 \mathrm{C}$ & $49.40 / 71.66$ & 629.0 \\
$737 \mathrm{~A}$ & $50.23 / 73.03$ & 564.0 \\
$737 \mathrm{~B}$ & $50.23 / 73.03$ & 564.0 \\
$738 \mathrm{~A}$ & $62.71 / 82.78$ & 2252.7 \\
$738 \mathrm{~B}$ & $62.71 / 82.79$ & 2252.5 \\
$738 \mathrm{C}$ & $62.71 / 82.79$ & 2252.5 \\
$739 \mathrm{~A}$ & $67.28 / 71.77$ & 412.4 \\
$739 \mathrm{~B}$ & $67.28 / 71.77$ & 412.4 \\
$739 \mathrm{C}$ & $67.28 / 71.77$ & 412.4 \\
$740 \mathrm{~A}$ & $68.76 / 76.68$ & 807.5 \\
$740 \mathrm{~B}$ & $69.76 / 76.68$ & 814.4 \\
$741 \mathrm{~A}$ & $68.38 / 76.38$ & 551.4 \\
$742 \mathrm{~A}$ & $67.55 / 75.41$ & 415.7 \\
$743 \mathrm{~A}$ & $66.92 / 74.69$ & 988.7 \\
$744 \mathrm{~A}$ & $61.58 / 80.59$ & 2307.2 \\
$744 \mathrm{~B}$ & $61.56 / 80.59$ & 2306.5 \\
$744 \mathrm{C}$ & $61.58 / 80.59$ & 2308.0 \\
$745 \mathrm{~A}$ & $59.59 / 85.85$ & 4093.0 \\
$745 \mathrm{~B}$ & $59.59 / 85.85$ & 4082.5 \\
$746 \mathrm{~A}$ & $59.57 / 85.87$ & 4059.5 \\
\hline & & \\
\hline & &
\end{tabular}

that the temperature factor of $\delta^{18} \mathrm{O}$ records should be variable for the Oligocene, Miocene, and Pliocene.

Shackleton (1986) cited more accurate oxygen isotope measurements from deep-water sites and suggested that there must have been some ice on Antarctica at three times during the Oligocene: the earliest Oligocene, the middle part of the Oligocene, and the latest Oligocene. However, he reasoned that the early and middle Oligocene events represented temporary glaciations involving an ice sheet that terminated inland rather than at the coastline.

Miller et al. (1987) used a composite benthic foraminiferal oxygen isotope record of Cenozoic deep-sea sediments to propose that significant continental-sized ice sheets have existed on Antarctica since the beginning of the Oligocene (36-35 Ma); however, they pointed out that the ice sheets may have disappeared during parts of the Oligocene and early Miocene. They used covariance of the benthic and low- to middle-latitude planktonic $\delta^{18} \mathrm{O}$ records to infer several ice growth and decay events with growth at $35,31,25,14$, and $10 \mathrm{Ma}$ (time scale of Berggren et al., 1985).

More recently, Miller et al. (in press) have proposed a relationship between the rate of ${ }^{87} \mathrm{Sr} /{ }^{86} \mathrm{Sr}$ change in the oceans to Antarctic ice growth events revealed from $\delta^{18} \mathrm{O}$ records. They propose that the high rates of change of ${ }^{87} \mathrm{Sr} /{ }^{86} \mathrm{Sr}$ observed between the late Eocene (about $41 \mathrm{Ma}$ ) and the earliest middle Miocene (about $15 \mathrm{Ma}$ ) were caused by intermittent glaciations and deglaciations of east Antarctica during this interval which introduced sialic weathering products to the oceans in a series of pulses. Based on compilation of benthic and planktonic foraminiferal isotope data, Miller et al. (in press) call for ice growth events at approximately the following times: $41 \mathrm{Ma}, 36 \mathrm{Ma}, 32$ $\mathrm{Ma}, 28 \mathrm{Ma}, 23.5 \mathrm{Ma}, 21.3 \mathrm{Ma}, 18.1 \mathrm{Ma}$, and 16.1 Ma. After 15 Ma (time scale of Berggren et al., 1985) the rate of change of ${ }^{87} \mathrm{Sr} /{ }^{86} \mathrm{Sr}$ decreased until the latest Miocene, and Miller et al. (in press) argue for the establishment of a permanent ice cap in east Antarctica at this time. Nevertheless, they propose further ice growth events at 13.6, 12.6, 11.3, 9.6, and 8.5 Ma. Miller et al. (in press) go on to propose that increased rate of change of ${ }^{87} \mathrm{Sr} /$ ${ }^{86} \mathrm{Sr}$ observed between about 5.5 Ma and 4.5 Ma (latest Miocene to earliest Pliocene) is related to establishment of the West Antarctic Ice Sheet.
Wise et al. (in press) review some of the assumptions used in estimating ice volume from $\delta^{18} \mathrm{O}$ records, concluding that isotopic data must be compared with independent estimates of ice volume. For example, they argue that Keigwin and Corliss's (1986) relatively flat, early Oligocene isotopic gradient between high- and low-latitude regions for shallow-dwelling planktonic foraminifers conflicts with their calcareous nannofossil studies for the early Oligocene which show a pronounced latitudinal thermal gradient in the South Atlantic. In order to estimate temperature from Keigwin and Corliss's (1986) early Oligocene isotopic gradient, Wise et al. (in press) propose that a significant salinity effect at higher latitudes must also be considered. They suggest that precipitation most likely exceeded evaporation in the high latitudes, contributing to the salinity effect.

A different approach has been taken by Prentice and Matthews (1988) who, like Matthews and Poore (1980), suggest that tropical sea-surface temperatures have remained essentially stable throughout the Cenozoic, whereas bottom water temperatures have fluctuated significantly. Prentice and Matthews (1988) constructed composite $\delta^{18} \mathrm{O}$ curves for tropical shallow-dwelling planktonic and deep-water benthic foraminifers for the entire Cenozoic and assumed that the tropical $\delta^{18} \mathrm{O}$ data primarily recorded ice volume. Their reconstructions suggest that the last $\mathbf{4 2}$ m.y. (since the latest middle Eocene) have been typified by much more ice volume than exists today. Prentice and Matthews (1988) argue that the Paleocene and early Eocene (65-50 Ma) of Antarctica were essentially ice free, and they record minor icegrowth events to near-modern values at $49 \mathrm{Ma}$ (earliest middle Eocene), 47-46 Ma (middle Eocene), and $44 \mathrm{Ma}$ (late middle Eocene) prior to the growth of the ice sheet to modern and greater volumes at $42 \mathrm{Ma}$ (time scale of Berggren et al., 1985).

Thus, from the isotope studies we have one proposal that very little ice existed on Antarctica in the earliest Oligocene (Shackleton, 1986), another argument that significant ice was present in the earliest Oligocene but that ice sheet disappeared during parts of the Oligocene and early Miocene (Miller et al., 1987), and a third hypothesis that the volume of the Antarctic ice sheet has been continually equal to or greater in size than the modern ice sheet since the latest middle Eocene (Prentice and Matthews, 1988). A fourth hypothesis by Harwood (Harwood, 1987; Harwood et al., 1989c; and Harwood and Webb, 1990), calls for the interpretation of a variable ice volume component through time of $\delta^{18} \mathrm{O}$ records in order to reconcile that record with the glacial eustatic sea level record of Haq et al (1987) and with an inferred Oligocene to early Pliocene Antarctic history of multiple glaciations and deglaciations.

\section{Sediment Record}

The study of the surficial sediment/rock record of Antarctica to elucidate the Cenozoic history of Antarctic glaciation has been limited by the extensive ice coverage of the continent, the limited fossil content of the detrital-rich Cenozoic sediments, and the probable repeated disturbance of that record caused by the waxing and waning ice sheets. Webb (1990; in press) estimated that as much as $98 \%$ of all surficial bedrock Antarctica lies buried beneath the ice sheets.

Birkenmajer (1988) reported fossiliferous glaciomarine clastic deposits containing glacially striated iceberg-rafted dropstones from the South Shetland Islands of the Antarctic Peninsula. This sequence is capped by a basaltic lava dated at $49.4 \pm$ 5 Ma using K-Ar (early middle Eocene). Calcareous nannofossils from a hyaloclastite immediately below the lava yield a latest Paleocene through earliest Eocene age, and Birkenmajer (1988) speculated that the deposit represents a minor glacial event, related to a local glaciation of the highest mountain tops within the Antarctic Peninsula region. The absence of such a glacial 

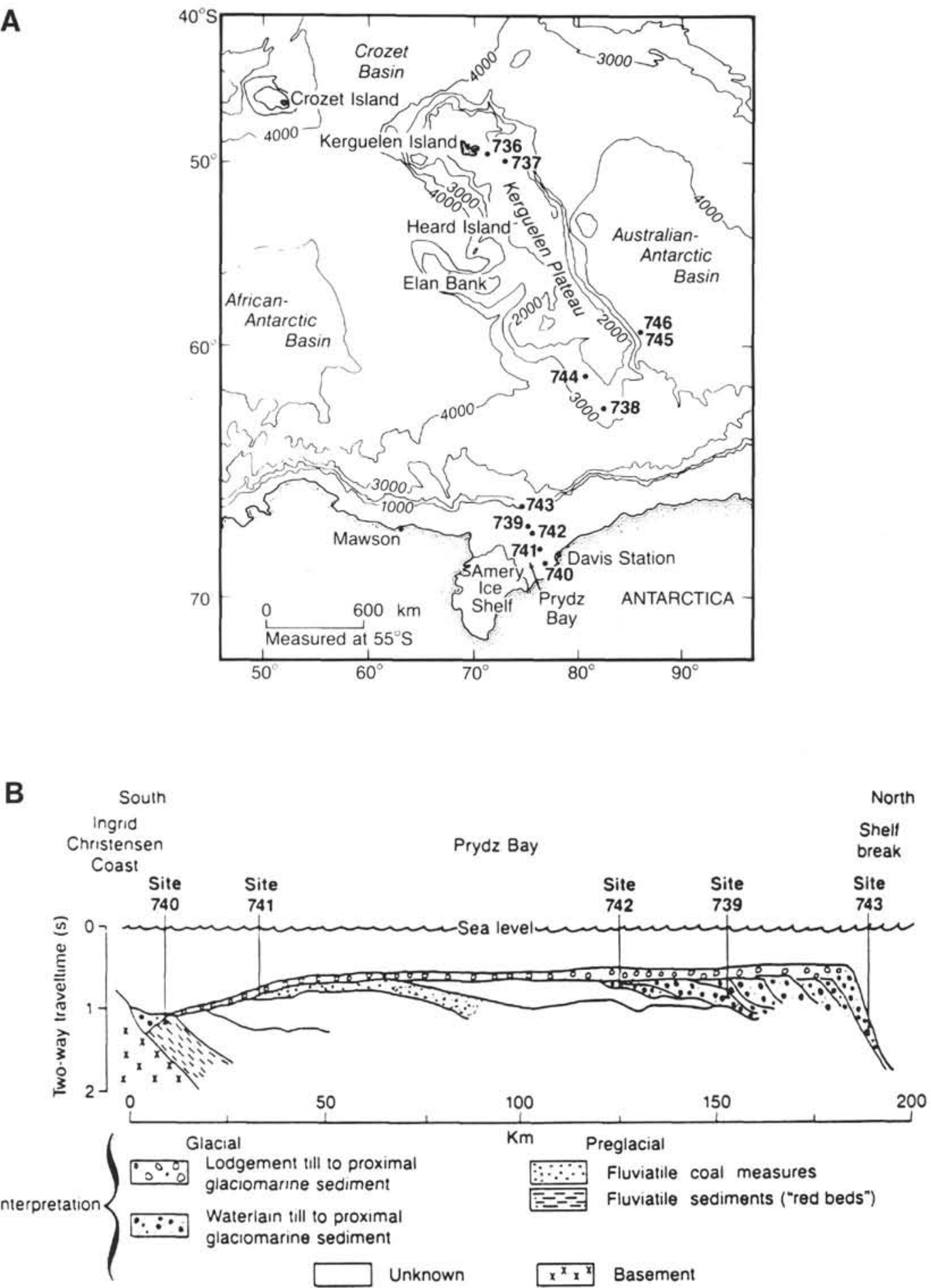

Figure 1. A. Location of Sites 736-743 occupied during ODP Leg 119. Bathymetry is in meters. B. South-north composite cross section for the sites occupied in Prydz Bay, East Antarctica. Profile is based on seismic records collected by JOIDES Resolution and previous records collected by Stagg (1985) (see Cooper et al., this volume, and Fig. 3).

event in the lower middle Eocene of Seymour Island (Zinsmeister, 1982) supports the local character of this glaciation.

Birkenmajer (1988) also documented glacially controlled terrestrial and marine deposits of the Polonez Cove Formation on the Antarctic Peninsula which are dated between 32.8 and 30 $\mathrm{Ma}$ (late early Oligocene) based on calcareous nannofossils and $\mathrm{K}-\mathrm{Ar}$ ages from the overlying lavas of the Legru Bay Group. Birkenmajer (1988) described a succeeding Legru glaciation dated at 29.5-25.7 Ma (late Oligocene) from glacial deposits within the Legru Group. In contrast to Birkenmajer's (1988) Eocene glacial sediments, these Oligocene glacial deposits are much more widespread on the Antarctic Peninsula and imply major regional glaciation.

Coring on the Antarctic continental shelf represents the best strategy to date the initiation of the Antarctic ice sheets, however, such coring has been rather limited. DSDP Leg 28 drilled 


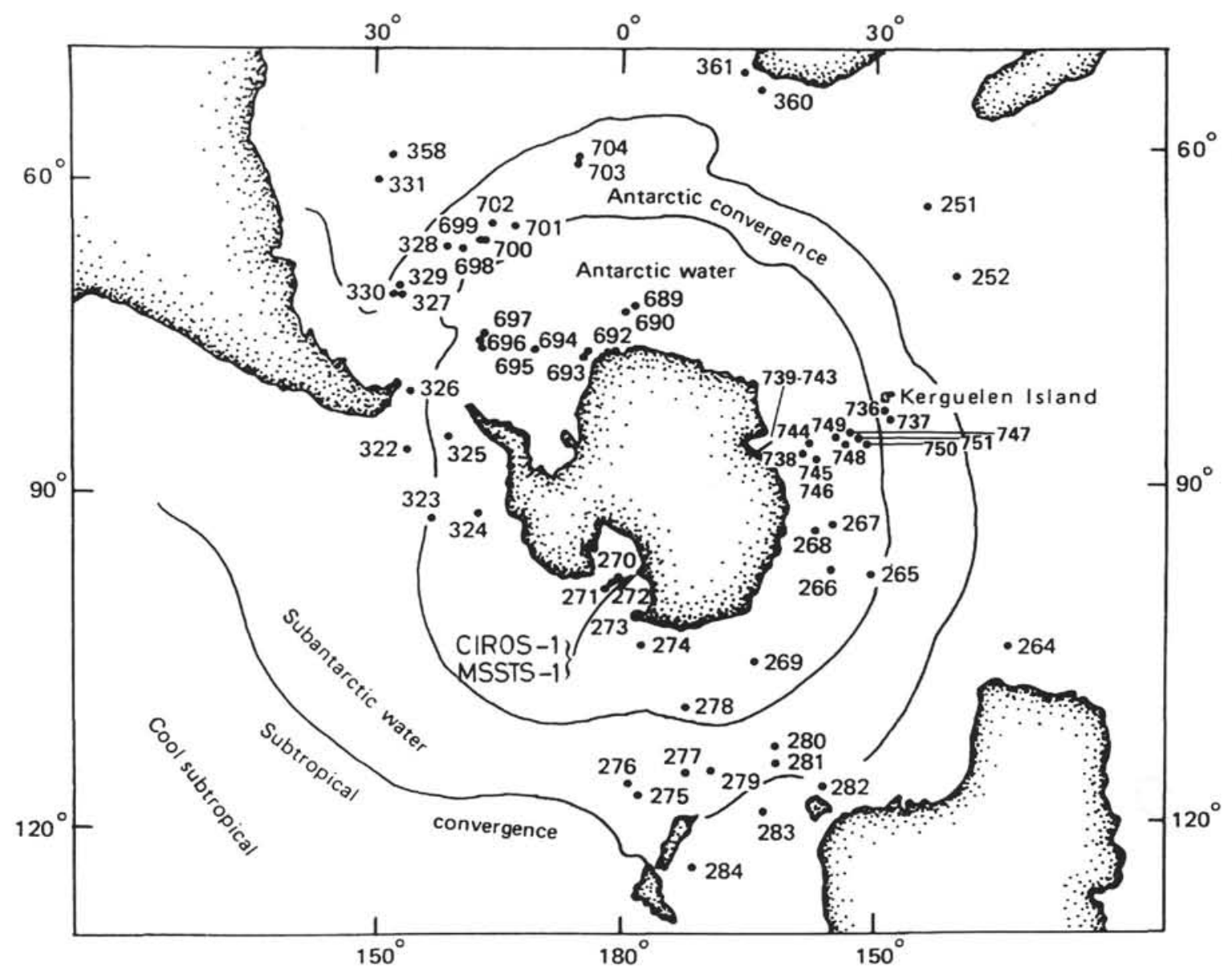

Figure 2. Present-day location of surface-water masses of the Southern Hemisphere (modified from Kennett, 1978, and Kennett and Barker, 1990). Numbers indicate DSDP and ODP sites.

four sites (270-273) in the Ross Sea as well as six sites (265-269 and 274) in adjacent deep-sea areas (Hayes, Frakes, et al., 1975). Upper Oligocene ( $\sim 25 \mathrm{Ma})$ glacial sediments were recovered at DSDP Site 270 (Hayes, Frakes, et al., 1975).

The 227-m-deep, MSSTS-1 drill hole was cored in $195 \mathrm{~m}$ of water adjacent to the ice sheet in the McMurdo Sound area of the Ross Sea (Barrett, 1986; Barrett et al., 1987). Upper Oligocene glacial sediments (as old as $27 \mathrm{Ma}$ ) were recovered (age updated by Harwood et al., 1989a) from MSSTS-1. The MSSTS-1 record was duplicated and extended in the CIROS-1 drill hole, which was completed less than $5 \mathrm{~km}$ from MSSTS-1 in $198 \mathrm{~m}$ of water. Coring in CIROS-1 reached a depth of $702 \mathrm{~m}$ below seafloor (mbsf), and the sediments recovered provided evidence of nearby glaciers calving at sea level in the earliest Oligocene (36.0 $\mathrm{Ma}$ ) and the presence of an extensive Antarctic ice sheet by the mid Oligocene. Within the upper Oligocene and lowermost Miocene (30.5 to about $22 \mathrm{Ma}$; Barrett et al., 1989; Harwood et al., 1989a), seven major advances and retreats of ice were recorded in the CIROS-1 drill hole, and Barrett et al. (1989) suggested that late Oligocene to early Miocene ice sheets were similar in size and character (temperate) to those of the Northern Hemisphere during the Quaternary, but they were of longer duration (several m.y. vs. 100 k.y.).

D. M. Harwood (pers. comm., 1990) emphasizes that the CIROS-1 record provides requisite marine and terrestrial paleotemperature data for use in interpreting isotopic data. He argues that the vegetation, soils, and lack of significant sea ice inferred from the CIROS-1 data (Barrett et al., 1989) all attest to warmer marine paleotemperatures than those assumed by Shackleton and Kennett (1975) for the earliest Oligocene of Antarctica. D. M. Harwood (pers. comm., 1990) points out that such warmer marine paleotemperatures in the seas around Antarctica must imply a greater ice-volume component in early Oligocene oxygen isotopic data that inferred from the Shackleton and Kennett (1975) approach.

The major unconformity in the CIROS-1 sequence (separating the lower Oligocene from the upper Oligocene to lowermost Miocene) marks a major shallowing event and the first time that ice was grounded over the CIROS-1 site. This mid-Oligocene unconformity can be traced by seismic stratigraphy throughout the Ross Sea, and is thought by both Bartek et al. (1989) and Barrett et al. (1989) to represent advance of an ice sheet to the shelf edge in the middle part of the Oligocene (about $30 \mathrm{Ma}$ ). The timing of this unconformity and shallowing event in CIROS-1 coincides with a major eustatic sea level drop as suggested by the sea-level curve of Haq et al. (1987). Bartek et al. (1989) cite the extent of this regional unconformity to argue that this first major ice sheet grounding event in the Ross Sea during the late Oligocene was comparable in lateral extent with that of the Wisconsin glacial maximum; however, the ice sheet might have been much thinner than the present-day West Antarctic Ice Sheet, because the shelf was probably shallower (J. Anderson, pers. comm., 1990).

Reworking of microfossils is a pervasive problem in nearshore Antarctic sediments. Where older calcareous nannofossil assemblages from the Paleogene are reworked into Neogene sed- 
iments barren of calcareous nannofossils, obvious problems with dating can occur. Diverse diatom assemblages, however, typify Oligocene and younger Antarctic marginal sediments, and Harwood (1986a, b; 1989) and Harwood et al. (1989) demonstrate that reworked diatom assemblages are relatively easy to distinguish in Oligocene and younger sediments.

\section{Modelling}

In addition to the preceding physical and chemical evidence, recent studies have attempted to model the growth of the Antarctic ice sheet. Oerlemanns (1982) developed a numerical model for the Antarctic ice sheet sensitive to bedrock adjustment, the rate of snowfall, and ice/snow melt which is able to produce the major features of the modern Antarctic ice sheet. A significant result of Oerlemanns' (1982) model proposes that a $9^{\circ} \mathrm{C}$ warming of the Southern Ocean could lead to thicker ice in the central portions of the East Antarctic Ice Sheet and that substantial ice caps would remain on parts of the Antarctic continent even if further warming of $5^{\circ}-10^{\circ} \mathrm{C}$ occurred. D. M Harwood (pers. comm., 1990), however, argues that such ice sheets produced in connection with warmer sea surface temperatures and higher precipitation would likely have faster ice flow rates and less steep profiles, so that thickening of the ice sheet due to warming may only be temporary.

In modelling the Antarctic ice sheet it is important to distinguish between marine-based ice sheets such as that of West Antarctica which are based below sea level and buttressed on pinning points and continental ice sheets such as that of East Antarctica which are based above sea level (Anderson et al., 1980; J. Anderson, pers. comm., 1990). The former type of ice sheet is relatively unstable and may become unpinned by changes in sea level, isostatic depression of the sea floor, or erosion resulting in rapid deglaciation (Bartek, 1989).

Robin (1988) developed a glaciological model for the history of the Antarctic ice sheet over the past $100 \mathrm{~m}$.y. based on the changes of the equilibrium line altitude of snow accumulation with time, the relation of the snow/ice accumulation rate with global temperature, and basal melting of ice shelves by ocean waters. He constrained his model by geological evidence from Antarctica to suggest that extensive glaciation of East Antarctica commenced after $40 \mathrm{Ma}$. A switch to a different climate-ice equilibrium state at $20 \mathrm{Ma}$ prevented any major deglaciation, and a further climate-ice switch at $10 \mathrm{Ma}$ lead to the rapid formation of ice shelves and the marine ice sheet of West Antarctica. Robin (1988) suggested that retreat of the ice sheet caused by global cooling has been dominant since $5 \mathrm{Ma}$.

Modelling of atmospheric circulation by Ross (in Bartek, 1989) suggests that the final separation of the Antarctic/Australia landmass in the middle Eocene would have caused large low pressure centers to develop over Antarctica and that winds approaching Antarctica would traverse a broad, relatively warm seaway which would allow them to become more moisture-laden relative to the pre-break-up situation. The resulting increased precipitation on a cold continent could lead to growth of an extensive ice sheet on Antarctica during the later Eocene. Furthermore, development of these low pressure cells could also influence the development of the Antarctic Divergence and upwelling strength, leading to cooling of subantarctic surface waters and increased deposition of biosiliceous sediments (Foldvik and Gammelsrød 1988).

Additional proxy records such as ice-rafted detritus, pollen, clay mineralogy, and biogenic sediments from deep-sea sediments recovered around the margins of Antarctica have been used to address the glacial history of Antarctica during the Cenozoic. However, such records are not a direct measurement of the size and character of ice sheets and should be evaluated with caution (Anderson, 1986).

\section{Ice-Rafted Detritus Records}

The Cenozoic record of ice-rafted detritus around Antarctica is best studied in deep-sea pelagic sections where quartz and lithic fragments transported by icebergs contrast markedly from normal pelagic sediments (carbonate, biosiliceous, and deep-sea clays) and where the record is most complete and most easily dated. Ice-rafted detritus provides evidence of glaciers calving at sea level, but the absence of ice-rafted detritus in any given interval is not direct evidence of the absence of icebergs in Antarctic seas (Anderson et al., 1983). It should be remembered that tracts of icebergs may differ with differing sea-surface circulation, and the survivability of icebergs will depend of sea-surface temperatures. The presence or absence of sea ice is also a factor in iceberg transit time to the deep sea, because icebergs will not be quickly blown through a zone of sea ice and thus may melt at a more southerly location (D. M. Harwood, pers. comm., 1990). Denton et al. (in press) pointed out that ice-rafted detritus production is controlled by basal rock type (erodibility), the ice thermal regime (erosive capability and temperature of icebergs produced), ice flux to the grounding line, the presence or absence of ice shelves, and iceberg drift paths. Whether an increase in ice-rafted detritus reflects waxing (Tucholke et al., 1976; Kennett, 1977) or waning (Drewry and Cooper, 1981; Anderson et al., 1983) of ice sheets is currently unclear.

Prior to ODP Leg 119, the oldest probable ice-rafted detritus was of early Oligocene age from ODP Site 693 in the Weddell Sea (Barker and Kennett, et al., 1988). Tucholke et al. (1976) documented ice-rafted detritus of early late Oligocene age from DSDP Site 274 in the Ross Sea and pointed out that there appears to be a latitudinal control on the age of the first occurrence of ice-rafted detritus in the Southern Ocean; however, the tracks of icebergs around the Antarctic continent are complicated and the ice-rafted detritus records in the Pacific, Indian, and Atlantic sectors of the Southern Ocean are most likely diachronous (Tucholke et al., 1976).

Possible Eocene ice-rafted detritus was reported by Margolis and Kennett (1971) from Eltanin cores from the South Pacific, but whether this represents true ice-rafted detritus is open to debate. Wei (in press) recently studied the calcareous nannofossil biostratigraphy of these Eltanin cores and reports the following ages for this possible ice-rafted detritus:

1. Core E13-4 $\left(57^{\circ} 46^{\prime} \mathrm{S}, 90^{\circ} 48^{\prime} \mathrm{W}, 4700 \mathrm{~m}\right.$ water depth): calcareous nannofossil zone CP10-CP11, latest early Eocene and earliest Eocene (55.2-52.6 Ma).

2. Cores E24-8 $\left(2^{\circ} 53^{\prime} \mathrm{S}, 134^{\circ} 39^{\prime} \mathrm{W}, 5011 \mathrm{~m}\right.$ water depth) and E24-9 $\left(40^{\circ} 35^{\prime} \mathrm{S}, 135^{\circ} 16^{\prime} \mathrm{W}, 4837 \mathrm{~m}\right.$ water depth): calcareous nannofossils zones CP12b-CP13, middle Eocene; (52.045.4 Ma).

3. Core $24-10\left(37^{\circ} 58^{\prime} \mathrm{S}, 134^{\circ} 59^{\prime} \mathrm{W}, 4874 \mathrm{~m}\right.$ water depth): calcareous nannofossil Subzone CP14a, late middle Eocene (45.4-42.3 Ma).

Such ice-rafted detritus in the southeast Pacific, however, is likely to come from West Antarctica rather than East Antarctica, and other than Birkenmajer (1988), few researchers suggest substantial glaciation of West Antarctica prior to the late Miocene (Denton et al., in press; Kennett and Barker, 1990).

\section{Antarctic Pollen Record}

Kennett (1977) suggested that the presence of widespread in situ pollen in Eocene and Oligocene Antarctic sediments is evidence of macrovegetation on the Antarctic continent and argued against the presence of a continental-sized ice sheet during these times. However, as pointed out by Barrett et al. (1989), the recovery of palynomorphs and fossil plant material from upper 
Oligocene and lower Miocene glacial marine sediments from the Ross Sea (Kemp and Barrett, 1975; Mildenhall, 1989; Hill, 1989) does not preclude the presence of an ice sheet in Antarctica during parts of the Oligocene. Indeed, such plant material occurs in upper Oligocene interglacial sediments deposited between glacial diamictites in the CIROS-1 drill hole, and Webb et al. (1984) reported plant fossils of Pliocene age, long after the first ice sheets formed. Presumably, coastal enclaves of vegetation may have survived through repeated glacial advances in the late Oligocene and, possibly, into the Pliocene.

\section{Clay Mineralogy}

Barker et al. (1988) pointed out that the dominance of smectite in the Eocene of ODP Site 690 from the Maud Rise indicates that chemical weathering rather than the physical weathering was active on East Antarctica during the Eocene, thus precluding extensive glaciation. A major change from smectite-dominated clay mineral assemblages to illite-dominated assemblages that is recorded in the lowermost Oligocene from throughout the Southern Ocean (Barker et al., 1988; Barron, Larsen, et al., 1989; Schlich, Wise, et al., 1989) seemingly represents evidence of major cryospheric development at that time. As noted by Bartek (1989) and Ehrmann (this volume), however, higher values of smectite in deep-sea sediments deposited around the margins of Antarctica may also be due to erosion of sediments containing smectite clays from the Antarctic continent by glacial processes, so caution in interpreting the clay mineralogy of deep-sea sediments is warranted.

\section{Biogenic Sediments}

The present-day Antarctic Polar Frontal Zone marks the approximate boundary between biosiliceous sediments deposited in Subantarctic and Antarctic waters to the south and dominantly carbonate sediments deposited in subtropical waters to the north (Lisitzin, 1972). Ciesielski and Weaver (1983) noted that the first occurrence of biosiliceous sediments in deep-sea cores around Antarctica shows a latitudinal migration with time away from the Antarctic continent which they interpreted as indicating progressive cooling of Antarctic waters.

Baldauf and Barron (1990) reviewed the Cenozoic development of biosiliceous sediments in the various oceans. Their study revealed that biosiliceous sedimentation expanded greatly in geographic area in the Southern Ocean during the earliest Oligocene. Similarly, Kennett and Barker (1990) noted that a siliceous biogenic facies began to replace a carbonate facies on Maud Rise during the latest Eocene to earliest Oligocene. Clearly, this enhanced biosiliceous sedimentation reflects increased surface productivity, most likely resulting from the establishment of oceanic frontal systems in response to intensified winds and cooling of surface waters. Although expanded biosiliceous sedimentation in the Southern Ocean during the earliest Oligocene is supportive of high-latitude cooling, it is not direct evidence of the size of an Antarctic ice sheet, particularly if such an ice sheet is more temperate in character, such as the Northern Hemisphere ice sheets of the Pleistocene (Barrett et al., 1989).

\section{Biogeography}

The histories of the Subtropical Convergence and the Antarctic Polar Frontal Zone and their earlier analogs can also be determined by the changes in microfossil assemblages that occur across these surface water boundaries. Today, distinct assemblages of diatoms (Burckle, 1984), radiolarians (Morley, 1989), calcareous nannofossils (Haq, 1980), and planktonic foraminifers (Kennett, 1978) occur in sediment deposited on either side of these oceanic fronts. An excellent review by Kennett and Barker (1990) shows that progressive cooling in the Southern
Ocean during the middle and late Eocene resulted in declining diversities of calcareous microfossils. The earliest Oligocene brought further drops in diversity (from about 5 to 2 species of planktonic foraminifers and from about 9 to 12 to 3 to 8 species of calcareous nannofossils according to Kennett and Barker (in press). Wise et al. (1985) also noted a decrease in the diversity of foraminifers and calcareous nannofossils during the late Eocene and early Oligocene in the Falkland Plateau region of the South Atlantic, and they observed the replacement of radiolarians indicative of warmer waters by those indicative of cooler waters. Wise et al. (in press) argued that a relatively steep latitudinal sea-surface temperature gradient had developed by the early Oligocene in the Southern Ocean based on their estimated latitudinal biogeographic gradient for calcareous nannofossils and on oxygen isotopic data corrected for ice volume.

\section{Deep-Sea Hiatuses}

Deep-sea hiatuses are commonly linked to increases in bottom-water velocity and Antarctic ice volume (Keller and Barron, 1983). Numerous authors (Kennett et al., 1972, 1975; Moore et al., 1978; and Barker et al., 1988) have argued that extensive Oligocene hiatuses in the Tasman Sea, Coral Sea, and other regions of the world owed their origin to intensified oceanic circulation associated Antarctic cryospheric development.

Antarctic Bottom Water (AABW) is usually active at depths below $4200 \mathrm{~m}$, and Circumpolar Deep Water (CPW) occurs above $4200 \mathrm{~m}$ and is formed by mixing of AABW (more specifically, Weddell Sea Bottom Water) and North Atlantic Deep Water (NADW) in the South Atlantic. These water masses have been inferred by Ciesielski et al. (1982), Ledbetter and Ciesielski (1982), and Osborn et al. (1983) to be responsible for deep-sea hiatuses in the Atlantic and southeast Indian sectors of the Southern Ocean. Osborn et al. (1983) pointed out that deepand shallow-water hiatuses were not synchronous, emphasizing the differences between AABW and CPW. Even if deep-sea hiatuses result from increased production of either AABW or $\mathrm{CPW}$, it is presently unclear how the Antarctic ice sheet affects the formation of either water mass.

Ciesielski et al. (1982) suggested that increased production of AABW occurs when ice sheets increase in size and sea water at the bottom of ice shelves is frozen; thus implying a direct relationship between deep-sea hiatuses, increased flux of AABW, and waxing of the ice sheet. Foster and Carmack (1976), Ackley (1979), and Foldvik and Gammelsrød (1988), on the other hand, believe that increases in AABW production are linked to increases in the production of sea ice on the continental shelves and this implies increases are more likely during interglacial periods when ice shelves are limited on the continental shelves (Gordon, 1971: Broecker and Peng, 1982). Furthermore, the Antarctic shelf has been over-deepened by glacial erosion and isostasy. This changes the volume of shelf water masses and has a direct influence on AABW production (Anderson, 1989).

Denton et al. (in press) noted that it is presently unclear whether deep-sea hiatuses in the Southern Ocean are caused by high-velocity currents, whether they are regional in extent, and whether any variations in bottom-current velocities are related to size variations in ice sheets. Furthermore, the biostratigraphy used in identifying hiatuses needs to be reassessed in light of recent studies showing considerable diachroneity with latitude of microfossil ranges in the Neogene of the Southern Ocean (Burckle and Abrams, 1987). Anderson (1986) pointed out that deepsea hiatuses caused by current scour should be marked by coarse lag deposits composed of ice-rafted detritus, but such lag deposits are commonly lacking at those intervals where the hiatuses supposedly occur. The deep-sea hiatuses of the Weddell Sea inferred by Ledbetter and Ciesielski (1986) to reflect episodes of increased AABW flow have been shown to occur 
within the Weddell Fan (Anderson et al., 1986) and are thus highly suspect.

\section{Summary of Previous Studies}

The overwhelming evidence from these studies calls for the growth of the East Antarctic ice sheet to a detectable size in the earliest Oligocene. The size and stability of that initial ice sheet, however, continue to be debated. This debate can be summarized into the following hypotheses: (1) the existence of an ice sheet on East Antarctica only a small fraction of its present-day size in the earliest Oligocene with incremental stepwise growth in the middle Miocene, late Miocene, and late Pliocene (Shackleton and Kennett, 1975; Shackleton, 1986; Barker et al., 1988; Kennett and Barker, 1990); (2) the presence of a significant continental ice sheet on Antarctica since the earliest Oligocene (36$35 \mathrm{Ma}$ ) with several subsequent growth and decay events (Wise et al., 1985; Miller et al., 1987); (3) an Antarctic ice sheet equal to or greater in size than the present ice sheet since the late middle Eocene (42 Ma) with no major events of deglaciation (Prentice and Matthews (1988); (4) ice sheet or ice caps present in East Antarctica in the earliest Oligocene with growth to the size of the modern ice sheet during the early late Oligocene, major fluctuations in ice sheet size comparable to those of the Quaternary during the late Oligocene and early Miocene with those ice sheets being temperate in character and much like the Pleistocene continental ice sheets of North America (Barrett et al., 1989); and (5) large-scale fluctuations in ice sheet size during the Cenozoic including numerous major events of deglaciation which resulted in the opening of seaways in East Antarctica as late as the late Pliocene (Webb, 1990; Webb et al., 1984). Harwood (Harwood, 1987; Harwood et al., 1986c; Harwood and Webb, 1990) combines the last two hypotheses arguing that the variability seen in the CIROS-1 drill hole is a good analogue for the character and style of the subsequent Cenozoic glacial history of Antarctica and that several growth and decay events of different "temperate" ice sheets occurred through the mid Pliocene. D. M. Harwood (pers. comm., 1990) suggests that the profile of these "temperate" Oligocene to early Pliocene ice sheets was pancake-like (flat) compared to the domed-shaped profile of the late Pliocene and younger polar ice sheets.

\section{LEG 119 RESULTS}

Leg 119 was the first ODP leg to drill on the Antarctic continental shelf and the first deep-sea drilling cruise since DSDP Leg 28 (1973) to combine the study of pelagic sediments and their proxy record of Antarctic glaciation (ice-rafted detritus, oxygen isotopes, clay mineralogy, pelagic sediment type, and microfossil assemblages) with study of actual glacial sediments and processes on the Antarctic shelf.

Observations on the Cenozoic history of Antarctic glaciation from the Prydz Bay portion of Leg 119 are provided in papers published in this volume by Hambrey et al. (sediments), Cooper et al. (seismic stratigraphy), Solheim et al. (physical properties), and Ollier and Mathis (logging). Kerguelen Plateau sediment studies in this volume by Ehrmann (Sites 738 and 744), Bohrmann and Ehrmann (Sites 737, 738, and 744), and Ehrmann et al. (Sites 745 and 746) offer interpretations of Cenozoic Antarctic glacial history from observations of ice-rafted detritus, clay mineralogy, and pelagic sediment type. Oxygen isotope studies by Barrera and Huber (this volume) of Southern Kerguelen Plateau Sites 738 and 744 provide further observations. Ages from the biostratigraphy, chemostratigraphy, and magnetostratigraphy of these sediments are discussed in numerous papers in this volume and are summarized in Barron et al. (this volume). The geologic time scale of Berggren et al. (1985) is used in Leg 119 studies.
Leg 119 studies support the existence of glaciation in East Antarctica during parts of the late middle and late Eocene. Glacial sediments seemingly as old as $40.7 \mathrm{Ma}$ were recovered at Site 742 in Prydz Bay (Hambrey et al., this volume; Barron et al., this volume), and possibly ice-rafted detritus as old as 45 $\mathrm{Ma}$ is recorded from Site 738 on the southern tip of the Kerguelen Plateau (Ehrmann, this volume).

These Leg 119 studies also provide complementary evidence to support the presence of a continental-sized ice sheet in East Antarctica during the earliest Oligocene (36 Ma). In Prydz Bay, massive and weakly-stratified diamictite as well as minor diatomaceous mudstone recovered at Site 739 in Cores 119-739C-27R through 119-739C-39R (192.9-318.2 mbsf) contain diatoms, nannofossils, and dinoflagellates that together suggest an earliest Oligocene age (36-34.8 Ma; Barron et al., this volume). These glacial sediments indicate that the Lambert Glacier/Amery Ice Shelf complex was grounded near Site 739 in the earliest Oligocene, $140 \mathrm{~km}$ beyond the edge of the modern floating ice shelf, which implies the existence of a much larger ice sheet than that of the present (Hambrey et al., 1989, this volume). Inasmuch as the Lambert Glacier system presently drains $22 \%$ of East Antarctica, it is possible that early Oligocene glacial sediments present in Prydz Bay accurately reflect fluctuations in the East Antarctic ice sheet as a whole. The Prydz Bay shelf, however, may have been at much shallower depths during the early Oligocene (before overdeepening by grounded ice), and a thinner, pancake-like ice cap may have been present (J. B. Anderson and D. M. Harwood, pers. comm., 1990).

At Site 744 on the southern tip of the Kerguelen Plateau, more than $800 \mathrm{~km}$ northeast of Prydz Bay, the intensity of this $\sim 36$-Ma event is documented by large quantities of ice-rafted detritus, a change from smectite-dominated clay mineral assemblages to illite- and chlorite-dominated assemblages, an increase in biosiliceous sedimentation at the expense of carbonate sedimentation (Ehrmann, this volume), and a 1.15 per mil increase in $\delta^{18} \mathrm{O}$ of both benthic and planktonic foraminifers (Barrera and Huber, this volume). The synchroneity of these sedimentologic and isotopic events have also been observed in the CIROSI drill hole (Harwood et al., 1989a) and at ODP Site 748 on the central Kerguelen Plateau (Wise et al., in press).

Any evidence of the major middle Oligocene growth of the Antarctic ice sheet proposed by Barrett et al. (1989) and Bartek et al. (1989) in the Prydz Bay-Kerguelen area is secondary, as sediments of this age are removed at unconformities at Prydz Bay Site 739 and at southern Kerguelen Site 744 (Hambrey et al., this volume; Barron et al., this volume).

Some observations on the late Neogene history of Antarctic glaciation can be made based on the recovery of upper Miocene and younger glacial sediments in Prydz Bay and study of the sediment records from the sites drilled on the Kerguelen Plateau. Leg 119 data neither support nor contradict the major Neogene periods of deglaciation proposed by Webb et al. (1984) and Harwood (1986b), but they do provide evidence of waxing and waning of glaciers across the Prydz Bay shelf during the late Neogene and related fluctuations in the character of surface and deep water masses over the Kerguelen Plateau.

\section{The Prydz Bay Record}

Figure 3 shows a generalized cross section of the Prydz Bay continental shelf and slope and the locations of the five sites occupied during Leg 119 (Sites 739-743) in this region. The profile of the Prydz Bay shelf resembles that of other Antarctic and Arctic shelves in that it is deeper than most continental shelf areas and it contains an ice-eroded marginal channel, typically as deep as $1000 \mathrm{~m}$, which cuts into sediments immediately seaward of the edge of the basement outcrops (Cooper et al., this 

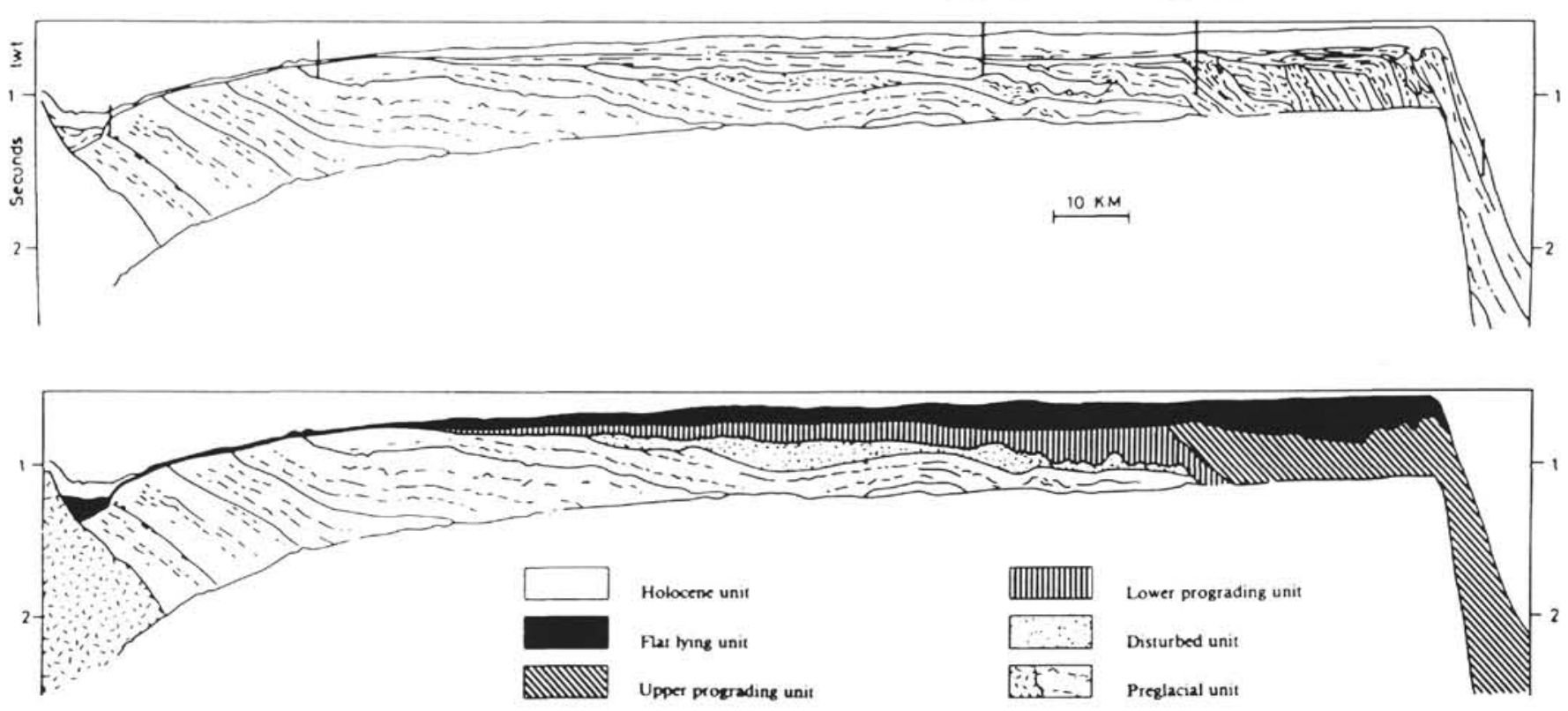

Figure 3. Composite seismic cross section of Prydz Bay from Cooper et al. (this volume) showing glacial and preglacial sediments (refer to Table 4).

volume; Hambrey et al., this volume). Seismic stratigraphy reveals that the main sediment sequence dips regionally seaward in the inner and outer part of the shelf but lies nearly flat over vast stretches of the central part of the shelf (Stagg, 1985; see Cooper et al., this volume). The upper part of this prograding sediment sequence is overlain by flat-lying sediments (Stagg, 1985) which are 30- to 150 -m thick and which truncate the older sediments (Cooper et al., this volume). The flat-lying sequence constitutes the banks on the outer part of the shelf, but it is missing under the huge transverse channel off the Amery Ice Shelf. Leg 119 drilling reveals that the flat-lying sediments and the prograding sediments cored on the outer part of the shelf at Sites 739 and 742 consist of a combined total of more than 700 $\mathrm{m}$ of diamictites with almost no recovered interstratified sorted sediments (Hambrey, this volume; Ollier and Mathis, this volume). The configuration and geographical setting of the seismic reflectors show that the upper prograding unit comprises sediments deposited on the upper paleo-continental slope, and that the flat-lying layers were deposited on the outer shelf. Thick sequences of diamictites are known from debris-flow deposits in alluvial fans (Rust and Koster, 1984), from the proximal parts of deep sea fans (Nelson and Nilsen, 1984), and in glacial environments (Flint, 1971). The first two environments can be discarded because of the morphological setting of Sites 739 and 742 near the shelf break, the lack of interbedding of sorted or graded layers, and the geometry of the sedimentary bodies. Besides their present-day setting only $140 \mathrm{~km}$ from the Amery Ice Shelf, the glacial character of the sediments is indicated by their poor sorting, wide range in grain shapes, mixed lithologies, mostly sparse occurrence or absence of fossils, presence of dropstones, and mineralogical immaturity (Hambrey et al., this volume). Striated stones are rare because the source rocks are weathered, but striae are seen on fine-grained clasts of coal and amphibolite. A grounded ice cover to the shelf edge is indicated by detailed facies analysis (Hambrey et al., this volume) and glacial loading demonstrated by the overconsolidation of the diamictites (Solheim et al., this volume). In summary, the upper flat-lying sediments and the prograding sediments cored on the outer part of the Prydz Bay shelf (Sites 739, 742, and 743) are glacial and marine in character, whereas the older sediments cored on the inner part of the shelf at Sites 740 and 741 are preglacial and continental in character (Turner, this volume, Turner and Padley, this volume) (Fig. 2).

At both Sites 739 and 742 on the outer portion of the Prydz Bay continental shelf, prograding glacial sediments (seismic unit PS.2a of Cooper, et al., this volume) of Oligocene and possibly Eocene age were cored beneath about $170 \mathrm{~m}$ of flat-lying Neogene sediments (Barron, Larsen, et al., 1989; Fig. 3 and Tables 2 and 3). Site 739 was chosen about $30 \mathrm{~km}$ landward from the shelf edge in Prydz Bay where seismic stratigraphy indicated a transition from generally flat-lying reflectors that characterize the middle parts of the Prydz Bay continental shelf to prograding reflectors that are typical of the outer part of the shelf (Cooper et al., this volume). Drilling at the site was aimed at dating this transition in reflector character with the hope that it represented the transition from preglacial to glacial sediments (Barron, Larsen, et al., 1989).

A 486.8-m-thick section of glacial diamictite was cored at Site 739 without reaching preglacial sediments (Fig. 4). Prograding sediments within the lower $313.2 \mathrm{~m}$ of the section are divisible by seismic stratigraphy into an upper, more steeply dipping sequence and a lower, more shallow-dipping sequence (seismic Units II and III of Barron, Larsen, et al., 1989) (Table 4). The boundary between these seismic units lies at about $310 \mathrm{mbsf}$, or approximately at the break between lithologic Units IV and V of Barron, Larsen, et al. (1989).

Coring was continued at Site 742, which lies landward from Site 739 , where seismic stratigraphy traced the shallow-dipping reflectors at the bottom of Hole $739 \mathrm{C}$ closer to the seafloor and where the top of an underlying acoustic unit, the distorted unit of Cooper et al. (this volume), lay relatively close (about $300 \mathrm{~m}$ ) to the seafloor (Barron, Larsen et al., 1989; Cooper et al., this volume; Fig. 3). Unfortunately, safety considerations limited coring at Site 742 to a maximum sub-bottom depth of $316 \mathrm{~m}$ (Fig. 5). Nevertheless, more than $130 \mathrm{~m}$ of strata underlying the section sampled at the base of Hole 739C (Cooper et al., this 
Table 2. Lithologic units cored at Site 739.

\begin{tabular}{|c|c|c|c|c|c|c|}
\hline Age & Unit & $\begin{array}{l}\text { Depth } \\
\text { (mbsf) }\end{array}$ & $\begin{array}{l}\text { Thickness } \\
(\mathrm{m})\end{array}$ & Core interval & Lithology & Sedimentary structures \\
\hline Quaternary & 1 & $0-24.1$ & 24.1 & $\begin{array}{l}739 \mathrm{~A}-1 \mathrm{H} \text { to }-2 \mathrm{H} \\
739 \mathrm{~B}-1 \mathrm{H} \text { to }-2 \mathrm{X} \\
739 \mathrm{C}-1 \mathrm{R} \text { to }-3 \mathrm{R}\end{array}$ & $\begin{array}{l}\text { Diamicton and pebbly sand-silt-clay with } \\
1 \%-10 \% \text { gravel and up to } 30 \% \\
\text { diatoms }\end{array}$ & $\begin{array}{l}\text { Structures not in evidence: because of drilling } \\
\text { disturbance. poor recovery }\end{array}$ \\
\hline---- & \multicolumn{6}{|c|}{ Contact not observed-no recovery interval } \\
\hline $\begin{array}{l}\text { late Miocene- } \\
\text { ?Quaternary }\end{array}$ & II & $24.1-173.6$ & 149.5 & $739 \mathrm{C}-4 \mathrm{R}$ to $-24 \mathrm{R}$ & $\begin{array}{l}\text { Massive diamicite; mainly } 10 \%-20 \% \\
\text { gravel, up to } 10 \% \text { diatoms }\end{array}$ & $\begin{array}{l}\text { Structureless with only slight variations in } \\
\text { gravel content }\end{array}$ \\
\hline \multirow[t]{5}{*}{----} & \multicolumn{6}{|c|}{ Contact not observed - no recovery interval } \\
\hline & IIIA & $173.6-192.9$ & 16.7 & $739 \mathrm{C}-25 \mathrm{R}$ to $-26 \mathrm{R}$ & $\begin{array}{l}\text { Stratified diamictite; gravel content } \\
\text { mainly } 1 \%-3 \% \text {, some diatoms }\end{array}$ & $\begin{array}{l}\text { Diffuse bedding, slickensides on faults, some } \\
\text { slumping }\end{array}$ \\
\hline & \multicolumn{6}{|c|}{ Contact not observed-no recovery interval } \\
\hline & IIIB & $192.9-198.1$ & 7.8 & $\begin{array}{l}739 \mathrm{C}-27 \mathrm{R}-1 \text { to } \\
-27 \mathrm{R}-\mathrm{CC}\end{array}$ & Sandy silty claystone; $30 \%$ diatoms & $\begin{array}{l}\text { Structures not in evidence; core mostly } \\
\text { broken by drilling }\end{array}$ \\
\hline & \multicolumn{6}{|c|}{ Contract not observed-no recovery interval } \\
\hline \multirow[t]{3}{*}{$\begin{array}{l}\text { early } \\
\text { Oligocene }\end{array}$} & IIIC & $198.1-267.2$ & 69.1 & $\begin{array}{l}739 \mathrm{C}-28 \mathrm{R}-1 \text { to } \\
-34 \mathrm{R}-3,84 \mathrm{~cm}\end{array}$ & $\begin{array}{l}\text { Stratified diamicite; gravel content } \\
\text { mainly } 3 \%-10 \%\end{array}$ & $\begin{array}{l}\text { Wispy bedding, slumps, loadstructures, } \\
\text { rhythmic laminations, burrows, and } \\
\text { faulted with slickensides near the top }\end{array}$ \\
\hline & \multicolumn{6}{|c|}{ Sharp erosional contact } \\
\hline & IV & $267.2-315.7$ & 48.5 & $\begin{array}{l}739 \mathrm{C}-34 \mathrm{R}-3 \\
84 \mathrm{~cm} \text { to }-39 \mathrm{R}-4 \\
30 \mathrm{~cm}\end{array}$ & $\begin{array}{l}\text { Massive diamictite; gravel content } \\
\text { mainly } 5 \%-10 \% \text {; diatoms up to } \\
15 \%\end{array}$ & $\begin{array}{l}\text { Structureless, except for minor laminae } \\
\text { resulting from drilling }\end{array}$ \\
\hline$---\cdots$ & \multicolumn{6}{|c|}{ Transitional contact } \\
\hline $\begin{array}{l}\text { ?middle } \\
\text { Eocene to } \\
\text { Oligocene }\end{array}$ & V & $315.7-486.8$ & 171.1 & $\begin{array}{l}739 \mathrm{C}-39 \mathrm{R}-4 \\
30 \mathrm{~cm} \text {, to } \\
-62 \mathrm{R}-\mathrm{CC}\end{array}$ & $\begin{array}{l}\text { Massive diamictite with calcareous } \\
\text { cement in horizons about } 10 \mathrm{~cm} \\
\text { thick; gravel content mainly } 1 \% \text { - } \\
3 \% \text {, unfossiliferous }\end{array}$ & $\begin{array}{l}\text { Structureless, badly broken in large part by } \\
\text { drilling }\end{array}$ \\
\hline
\end{tabular}

Table 3. Lithologic units cored at Site $\mathbf{7 4 2 .}$

\begin{tabular}{|c|c|c|c|c|c|}
\hline $\begin{array}{l}\text { Lithologic } \\
\text { Unit }\end{array}$ & Age & $\begin{array}{l}\text { Recovery } \\
\text { range }\end{array}$ & $\begin{array}{l}\text { Depth } \\
\text { (mbsf) }\end{array}$ & $\begin{array}{l}\text { Thickness } \\
(\mathrm{m})\end{array}$ & Lithology \\
\hline IA & late Quaternary & $1 \mathrm{R}-1,0-7 \mathrm{~cm}$ & $0-0.07$ & 0.1 & Diatomaceous sand-silt \\
\hline IB & & $\begin{array}{l}\text { IR-1, } 7 \mathrm{~cm} \text {, to } \\
2 \mathrm{R}-1,90 \mathrm{~cm}\end{array}$ & $0.07-5.4$ & 5.3 & Massive pebbly diamicton (up to $15 \%$ gravel) \\
\hline II & Quaternary-late Pliocene & $\begin{array}{l}2 \mathrm{R}-1,90 \mathrm{~cm}, \text { to } \\
14 \mathrm{R}-2, ? 49 \mathrm{~cm}\end{array}$ & $5.4-115.2$ & 109.8 & $\begin{array}{l}\text { Homogeneous massive diamictite with } \\
\text { pebbles and boulders (up to } 15 \% \text { gravel) }\end{array}$ \\
\hline IIIA & & $\begin{array}{l}14 \mathrm{R}-2, ? 49 \mathrm{~cm}, \text { to } \\
15 \mathrm{R}-2,20 \mathrm{~cm}\end{array}$ & $115.2-127.7$ & 12.5 & Stratified diamictite (average $5 \%$ gravel) \\
\hline IIIB & late Pliocene & $15 \mathrm{R}-4,20-80 \mathrm{~cm}$ & $127.7-128.3$ & 0.6 & Diatomite with minor silt and clay \\
\hline IIIC & & $\begin{array}{l}15 \mathrm{R}-4,80 \mathrm{~cm} \text {, to } \\
16 \mathrm{R}-1,96 \mathrm{~cm}\end{array}$ & $128.3-133.7$ & 5.4 & Stratified diamictite, sandstone, and siltstone \\
\hline IIID & & $\begin{array}{l}16 \mathrm{R}-1,96 \mathrm{~cm} \text {, to } \\
16 \mathrm{R}-2,17 \mathrm{~cm}\end{array}$ & $133.7-134.4$ & 0.7 & Boulders and pebbles probably in diamictite \\
\hline IV & & $\begin{array}{l}16 \mathrm{R}-2,17 \mathrm{~cm} \text {, to } \\
20 \mathrm{R}-1,131 \mathrm{~cm}\end{array}$ & $134.4-172.5$ & 38.1 & $\begin{array}{l}\text { Diamictite with diffuse layering ( } 1 \%-5 \% \\
\text { gravel) }\end{array}$ \\
\hline V & ?Oligocene-Eocene & $\begin{array}{l}20 \mathrm{R}-1,131 \mathrm{~cm} \text {, to } \\
33 \mathrm{R}-6,9 \mathrm{~cm}\end{array}$ & $172.5-304.3$ & 131.8 & $\begin{array}{l}\text { Pale diamictite with minor carbonate rich } \\
\text { layers }(1 \%-5 \% \text { gravel })\end{array}$ \\
\hline VIA & & $\begin{array}{l}33 \mathrm{R}-6,9 \mathrm{~cm} \text { to } \\
34 \mathrm{R}-1,120 \mathrm{~cm}\end{array}$ & $304.3-307.5$ & 3.2 & $\begin{array}{l}\text { Interbedded sand-silt claystones (with gravel) } \\
\text { and silty claystones }\end{array}$ \\
\hline VIB & & $\begin{array}{l}34 \mathrm{R}-1,120 \mathrm{~cm} \text {, to } \\
34 \mathrm{R}-5,95 \mathrm{~cm}\end{array}$ & $307.5-313.3$ & 5.8 & Pale massive diamictite ( $1 \%-5 \%$ gravel) \\
\hline VIC & early Eocene-Oligocene & $\begin{array}{l}34 \mathrm{R}-5,95 \mathrm{~cm}, \text { to } \\
34 \mathrm{R}-\mathrm{CC}\end{array}$ & $313.3-316.0$ & 2.7 & $\begin{array}{l}\text { Carbonaceous, well-sorted sand and silt- } \\
\text { stone with interbedded diamicite }\end{array}$ \\
\hline
\end{tabular}

volume) was cored in the lower part of Hole 742A (172.5-316 mbsf; Table 4) (see Hambrey et al., this volume, for a detailed description of these sediments).

According to Cooper et al. (this volume), drilling at Site 742 sampled the uppermost part of a seismically-distorted unit that corresponds to the deformed sands and carbonaceous shales of likely glacio-tectonic origin found in lithologic Unit VI of Barron, Larsen, et al. (1989) between 304.3 and 316.0 mbsf (Figs. 3,5 ). Cooper et al. (this volume) reasoned that the unconformity between glacial and preglacial sediments at Site 742 lies at the base of this distorted unit, or about $120 \mathrm{~m}$ below the base of Hole 742A (Fig. 3). Thus, Cooper et al. (this volume) suggested 


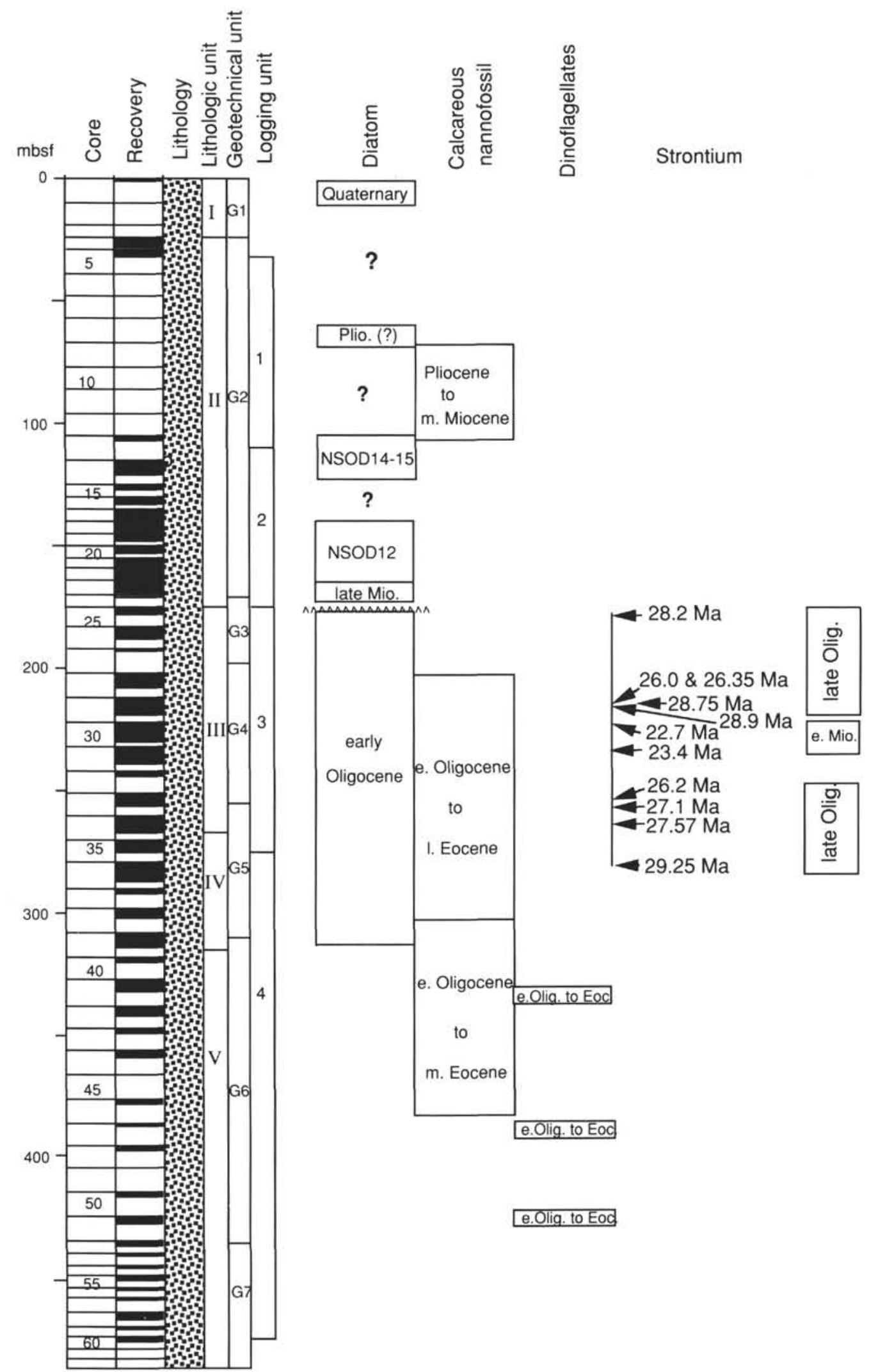

$500-$

Figure 4. Stratigraphic and chronologic summary for Site 739, Prydz Bay. The 486.9 $\mathrm{m}$ of diamictite recovered at this site can be subdivided into several lithologic, geotechnical, and logging units. Chronological control is based on analysis of diatoms, calcareous nannofossils, dinoflagellates, and strontium isotopes. 


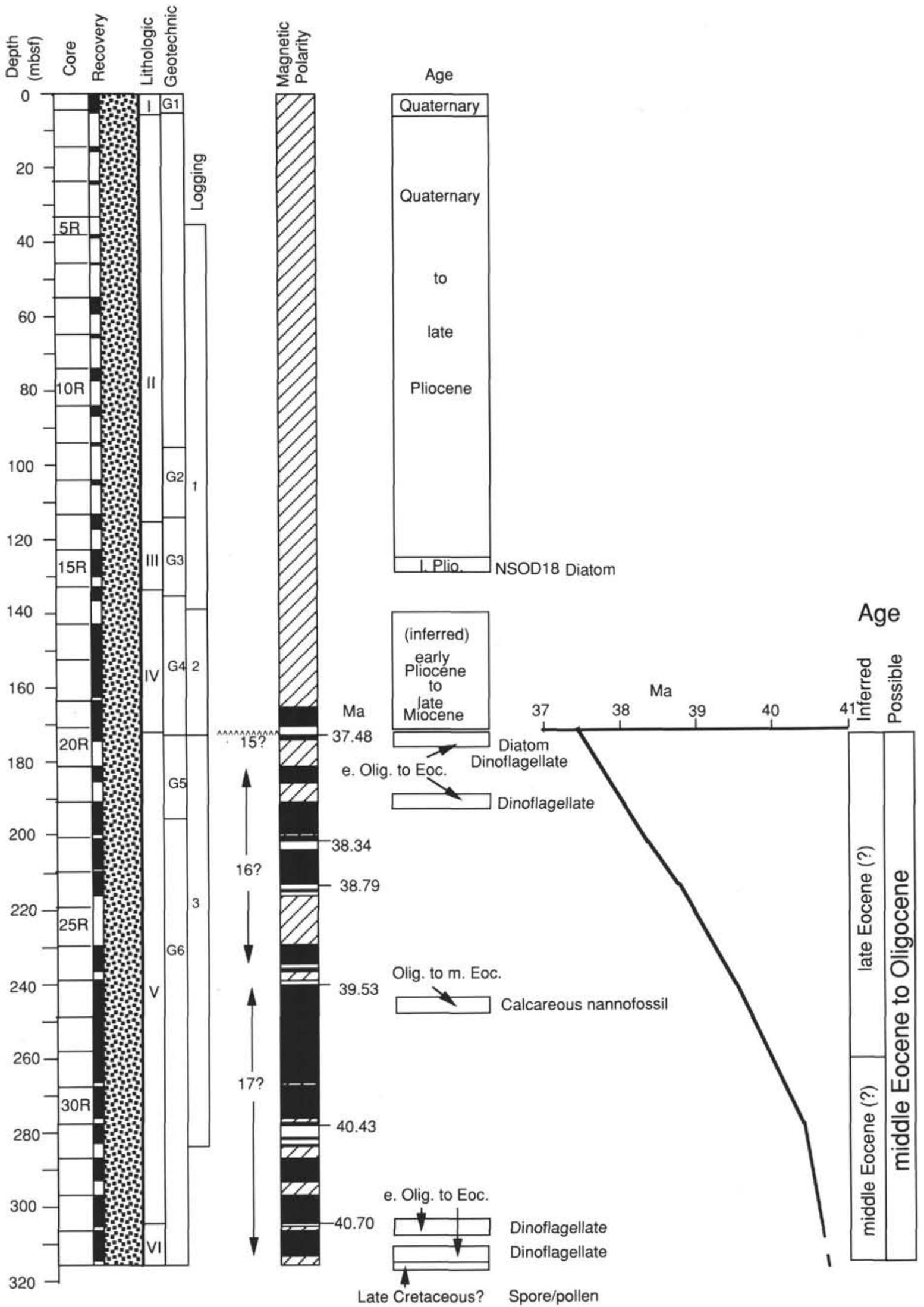

Figure 5. Stratigraphic and chronologic summary for Site 742, Prydz Bay. The $316 \mathrm{~m}$ of diamictite recovered at this site can be subdivided into numerous lithologic, geotechnical, and logging units. Chronological control is based on analysis of paleomagnetics (black representing normal, white representing reversed signatures, and diagonal lines representing lack of magnetic results), diatoms, calcareous nannofossils, and dinoflagellates. Sedimentation rates average $70 \mathrm{~m} / \mathrm{m} . \mathrm{y}$. for the middle Eocene? and $35 \mathrm{~m} / \mathrm{m} . \mathrm{y}$. for the late Eocene? 
Table 4. Paleogene glacial units in Prydz Bay.

\begin{tabular}{|c|c|c|c|c|c|c|c|}
\hline $\begin{array}{l}\text { Hole/ } \\
\text { interval } \\
\text { (mbsf) }\end{array}$ & $\begin{array}{l}\text { Age } \\
\text { (Ma) }\end{array}$ & $\begin{array}{l}\text { Seismic } \\
\text { character }\end{array}$ & Sediments & $\begin{array}{c}\text { Gravel } \\
\text { content } \\
(\%)\end{array}$ & $\begin{array}{c}\text { Clay } \\
\text { mineralogy }\end{array}$ & $\begin{array}{l}\text { Microfossil } \\
\text { content }\end{array}$ & Interpretation \\
\hline $739 \mathrm{C} / 173.6-310$ & $34.8-36.0$ & $\begin{array}{l}\text { Steeply dipping, } \\
\text { high variability } \\
\text { in continuity } \\
\text { and amplitude } \\
\text { (foreset) }\end{array}$ & $\begin{array}{l}\text { Massive and stratified } \\
\text { diamictites, } \\
\text { minor diatom } \\
\text { mudstone }\end{array}$ & $5-10$ & $\begin{array}{l}\text { Kaolinite } 10 \%-20 \% \\
\text { Illite }>50 \% \\
\text { Smectite } 10 \%-15 \% \\
\text { Chlorite } 20 \%\end{array}$ & $\begin{array}{l}\text { Moderate to } \\
\text { high-diatoms, } \\
\text { calcareous } \\
\text { nannofossils, } \\
\text { dinoflagellates }\end{array}$ & $\begin{array}{l}\text { Mostly water-laid and } \\
\text { proximal gla- } \\
\text { ciomarine till; } \\
\text { high energy; } \\
\text { upper slope } \\
\text { environment near } \\
\text { the front of a } \\
\text { grounded ice } \\
\text { sheet }\end{array}$ \\
\hline $\begin{array}{l}739 \mathrm{C} / 310-486.8 \\
742 \mathrm{~A} / 172.5-304.3\end{array}$ & $36 ?-40.7$ & $\begin{array}{l}\text { Gently dipping, } \\
\text { continuous, low } \\
\text { amplitude } \\
\text { (topset) }\end{array}$ & $\begin{array}{l}\text { Massive diamictites } \\
\text { (minor carbon- } \\
\text { ate) }\end{array}$ & $1-5$ & $\begin{array}{l}\text { Kaolinite }>40 \% \\
\text { Illite }<30 \% \\
\text { Smectite } 10 \%-20 \% \\
\text { Chlorite } 10 \%\end{array}$ & $\begin{array}{l}\text { Sparse and poor } \\
\text { diatoms, } \\
\text { calcareous } \\
\text { nannofossils, } \\
\text { dinoflagellates }\end{array}$ & $\begin{array}{l}\text { Water-laid till; low } \\
\text { energy, outer } \\
\text { continental shelf, } \\
\text { possible ice shelf }\end{array}$ \\
\hline $\begin{array}{l}742 \mathrm{~A} / 304.3-316.0 \\
\text { (probably to } 415 \text { ) }\end{array}$ & $>40.7$ & $\begin{array}{l}\text { "Distorted unit" } \\
\text { semicontinuous, } \\
\text { generally weak, } \\
\text { reflectors; } \\
\text { discordant w/ } \\
\text { overlying strata }\end{array}$ & $\begin{array}{l}\text { Variable: Massive } \\
\text { and stratified } \\
\text { diamictites, } \\
\text { laminated clay- } \\
\text { stone, (texturally- } \\
\text { sorted sandstone } \\
\text { and siltstone at } \\
\text { base) }\end{array}$ & ${ }^{a} 1-5$ & $\begin{array}{l}\text { Kaolinite } 80 \% \\
\text { Illite } 20 \% \\
\text { Smectite } 20 \% \\
\text { Chlorite } 10 \%\end{array}$ & $\begin{array}{l}\text { Sparse in situ } \\
\text { dinnoflagellates, } \\
\text { reworked } \\
\text { pollen glacial } \\
\text { deposition }\end{array}$ & $\begin{array}{l}\text { Glacial with some } \\
\text { periods of } \\
\text { simultaneous } \\
\text { fluvial/lacustrine }\end{array}$ \\
\hline
\end{tabular}

${ }^{\text {a }}$ Measured only in upper diamictite subunit.

that the onset of glacial conditions at Site 742 , which is presently $130 \mathrm{~km}$ seaward of the floating edge of the Amery Ice Shelf, predated the oldest sediments cored in Hole 742A.

Prograding sediments cored at Sites 739 and 742 are divisible into three distinct units based on seismic stratigraphy, lithostratigraphy, clay mineralogy, and fossil content (Tables 2-4). Massive and stratified diamictites recovered from a steeply dipping seismic unit between 173.6 and about 310 mbsf in Hole 739C contain a moderate but sporadic microfossil content (diatoms, calcareous nannofossils, and dinoflagellates), a relatively high gravel content $(5 \%-10 \%)$, and clay minerals dominated by illite rather than kaolinite ( $>50 \%$ vs. $10 \%-20 \%$ ). Massive diamictites in the underlying more gently dipping seismic unit at Sites 739 and 742 are characterized by minor carbonate, a low gravel content $(1 \%-5 \%)$, sparse and poorly preserved microfossils, and clay minerals dominated by kaolinite $(>40 \%)$ over illite $(<30 \%)$. The distorted seismic unit cored at the base of Hole 742A (304$316 \mathrm{mbsf}$ ) is characterized by variable lithologies-massive and stratified diamictites, laminated claystone, and texturally sorted sandstone and carbonaceous siltstone-which suggest some periods of simultaneous fluvial/lacustrine and glacial deposition (Hambrey et al., this volume; Cooper et al., this volume).

Age constraints of these glacial sediments are crucial to documenting the Cenozoic glacial history of the area. Unfortunately, low sediment recovery, extended intervals lacking microfossils, and the sporadic occurrences of reworked specimens hampers microfossil study in the glacial sequences recovered at Sites 739 and 742 . Diatoms provide the most stratigraphic control but calcareous nannofossils and dinoflagellates are also useful (Barron et al., this volume). These microfossils occur sporadically throughout the upper $315 \mathrm{~m}$ of the sedimentary sequence recovered from Site 739 (Fig. 4), and are extremely rare in the lower $171 \mathrm{~m}$ of Hole $739 \mathrm{C}$ as well as in most of the sequence recovered from Site 742 (Fig. 5). The common occurrence of distinctive diatom assemblages in Oligocene and younger Antarctic sediments allows reworking of assemblages to be readily recognized (Harwood, 1986a, 1986b, 1989; Harwood et al., 1989).

\section{Paleogene Sediments}

\section{Cores 119-739C-25R through $-39 R$}

Biostratigraphy suggests that the massive and stratified diamictite and minor diatomaceous mudstone (lithologic Units III and IV of Barron, Larsen, et al., 1989) recovered in Cores 119-739C25R through 119-739C-39R (173.6-315.7 mbsf) are early Oligocene in age (Barron et al., this volume; Fig. 4) (Barron et al., this volume). Dating of the lower Oligocene glacial sediments is extremely important, because together with lower Oligocene glacial sediments recovered in the CIROS-1 drill hole in the Ross Sea, they provide evidence of an East Antarctic ice sheet equal to or larger in size than the present ice sheet (Hambrey et al., 1989).

The distinctive early Oligocene diatom assemblage documented by Baldauf and Barron (this volume) from Cores 119-739C-25R through 119-739C-39R closely resembles diatom assemblage zone B of Harwood (1989) recovered from the CIROS-1 drill hole (Baldauf and Barron, this volume; D. M. Harwood, written comm., 1989), which is assigned an age of $34.5-36.0$ Ma by Harwood et al. (1989a). Calcareous nannofossil stratigraphy supports the diatom age assignments, although assemblages are very sporadic and show very low diversity and may be reworked (Wei and Thierstein, this volume). The presence of Isthmolithus recurvus in Samples 119-739C-28R-1, 30-32 cm, and 119-739C$30 \mathrm{R}-1,108-110 \mathrm{~cm}$, suggests a late Eocene to early Oligocene age of 38.8-34.8 Ma (Wei and Thierstein, this volume). Dinoflagellate assemblages recovered from 331,386 , and 426 mbsf in Hole 739C typify a provincial Antarctic flora of Eocene to early Oligocene age (Truswell, this volume), although they occur together with reworked Permian pollen and Cretaceous spores. Reworking of the lower Oligocene diatom assemblage can be ruled out, because none of the samples from this interval, Cores 119-739C-25R through 119-739C-39R, have yielded any of the distinctive late Oligocene or Neogene diatoms reported by Harwood $(1986 \mathrm{a}, 1989)$ from the upper Oligocene and lower Miocene of CIROS-1 and MSSTS-1 (Baldauf and Barron, this volume). 
Strontium isotope studies, however, on molluscan shells for the interval from 183.2 to $282.63 \mathrm{mbsf}$, an interval assigned to early Oligocene by diatoms and late Eocene to early Oligocene by calcareous nannofossils, suggest late Oligocene to earliest Miocene ages ranging from 29.95 to $22.7 \mathrm{Ma}$ (Thierstein et al., this volume; Fig. 4). The discrepancies between the $\mathrm{Sr}$ dating and the biostratigraphy are discussed in Thierstein et al. (this volume). The dating based on diatom and calcareous nannofossil biostratigraphy is considered to be the most reliable for the following reasons:

1. The Sr-dating method is based on the assumption the $\mathrm{Sr}$ isotope ratio in the shell material has not changed since its formation, an assumption that has been confirmed in pelagic sediments with minor immature terrigenous sediments (DePaolo and Ingram, 1985). However, Prydz Bay glacial sediments consist mainly of sedimentologically immature debris of old metamorphic and igneous rocks (Hambrey et al., this volume; Jenkins and Alibert, this volume) which are probably enriched in radiogenic ${ }^{87} \mathrm{Sr}$. Measurements by Thierstein et al. (this volume) show that the $\mathrm{Sr}$ content in the porewater is 1.5-2 times enriched in dissolved $\mathrm{Sr}$ relative to seawater with some of the highest ${ }^{87} \mathrm{SR}^{/ 86} \mathrm{Sr}$ isotope ratios recorded in DSDP and ODP sites, and significantly higher values occur in the shell fragments. Exchange between $\mathrm{Sr}$ in the pore water and the shells offers an explanation of the discordant ages (Thierstein et al., this volume). Negative correlation between $\mathrm{Mg}$ and $\mathrm{Sr}$ concentrations in the pore water may suggest that $\mathrm{Sr}$ is given off from ion exchange sites due to drastic changes in the concentration of $\mathrm{Mg}$ and $\mathrm{Ca}$ in the pore water; however, this needs further study.

2. Further support for an early Oligocene age for the shells comes from the study of diatoms in diatomaceous clay taken from an internal mold of a marine gastropod from Sample 119739C-30R-1, $108 \mathrm{~cm}$. This material contains a diverse and very well-preserved diatom assemblage of early Oligocene age similar in composition to that present in the surrounding diamictite. The assemblage includes a $400 \mu \mathrm{m}$-long delicate specimen of Sceptroneis lingulatus. It is not likely that this specimen is reworked, especially by glacial processes; therefore, the diatoms must be of the same age as the gastropod shell that contained them. However, this same shell was dated at $22.7 \mathrm{Ma}$ (early Miocene) by $\mathrm{Sr}$ isotopes (Thierstein et al., this volume).

3. An upsection trend toward younger ages that typifies the lower six $\mathrm{Sr}$ ages obtained by Thierstein et al. (this volume) is countered by relatively random ages obtained in the upper five measured samples (Fig. 4). Even if the upper five $\mathrm{Sr}$ ages are discarded, the resulting post-compaction sedimentation rate of 7.5 $\mathrm{m} / \mathrm{my}$ (Thierstein et al., this volume) is much too low for glaciomarine sediments deposited on the upper continental slope in the front of an ice sheet (Harwood et al., 1989a; Hambrey et al., this volume).

\section{Underlying Sediments}

More than $300 \mathrm{~m}$ of glacial sediments was recovered in a composite section from Holes $739 \mathrm{C}$ and $742 \mathrm{~A}$ beneath the welldated lowermost Oligocene diamictites of Cores 119-739C-25R through 119-739C-39R (173.6-318.2 mbsf; Figs. 3 and 4). Lithologic Unit V of Barron, Larsen, et al. (1989), immediately underlying the lowermost Oligocene diamictites in Hole $739 \mathrm{C}$ (315.7-486.8 mbsf), is a massive diamictite that is interpreted to represent water-laid till or proximal glaciomarine sediment (Hambrey et al., this volume). Analysis of sparse calcareous nannofossils and dinoflagellates suggests that this unit is middle Eocene to Oligocene (Barron et al., this volume; Fig. 4).

Correlation to Hole $742 \mathrm{~A}$ is provided by seismic stratigraphy (Cooper et al., this volume) and logging studies (Ollier and Mathis, this volume) which both suggest that the glacial diamic- tites of lithologic Unit V of Barron, Larsen et al., (1989) from 172.8 to 304.3 mbsf of Hole $742 \mathrm{~A}$ underlie basal lithologic Unit V of Hole 739C (Table 4). Microfossil age control in Unit V of Hole $742 \mathrm{~A}$ is limited to poorly preserved Eocene to early Oligocene diatoms (Pyxilla sp.) in Core 119-742A-20R (Baldauf and Barron, this volume), a middle Eocene to Oligocene calcareous nannofossil assemblage characterized by Reticulofenestra daviesii in Core 119-742A-27R (Wei and Thierstein, this volume), and provincial Eocene to early Oligocene dinoflagellates in Cores 119-742A-20R, 119-742A-22R, and 119-742A-33R (Truswell, this volume; Tocher in Barron, Larsen, et al., 1989; Fig. 5). Reworked Permian pollen and long-ranging Cretaceous to Tertiary spores and pollen are also present in the dinoflagellate samples (Truswell, this volume). The $\mathrm{Sr}$ isotopes of an aragonitic fragment of the marine shell Equiyoldia sp. from 267 mbsf (Site 742) suggest an age of $11.9 \mathrm{Ma}$ (E. Martin, pers. comm. 1990), a date which hardly can indicate the time of deposition.

This same 172.7-312.68 mbsf interval of Hole 742A has yielded a seemingly reliable magnetostratigraphy consisting of a mostly normal polarity sequence interrupted by eight short reversals (Sakai and Keating, this volume; Fig. 5). Shipboard cryogenic measurements were duplicated by shore laboratory study of discrete samples employing alternating field demagnetization. Assuming that the diatoms, calcareous nannofossils, and dinoflagellates of this interval are not reworked, one must look for this distinctive magnetic polarity signature within the Eocene and early Oligocene. In addition, this sequence lies well below the lower Oligocene sediments recovered between 173 and 318 mbsf in Hole 739C (Fig. 4) according to seismic stratigraphy (Cooper et al., this volume; Fig. 3; Table 4), so it must be Eocene or earliest Oligocene. As noted by Barron et al. (this volume), comparison with the geomagnetic time scale for this interval reveals only one interval, Chrons $15-18$, which is characterized by mostly normal polarity with numerous short reversals. A comparison of the downcore polarity log with the sequence from Subchron C15N-2 (37.46 Ma) to Subchron C17N-3 (40.8 Ma) (Fig. 5) shows relatively uniform post-compaction sedimentation rates of about $35 \mathrm{~m} / \mathrm{m} . \mathrm{y}$., quite similar to with the sedimentation rates obtained for other proximal glaciomarine sediments recovered from the paleomagnetically dated middle part of the sequence cored in the CIROS-1 drill hole (Harwood et al., 1989a).

At the base of Hole 742A, lithologic Unit VI (304.3-316.0 mbsf), which consists of interbedded siltstones and claystones, as well as minor diamictites, also contains a provincial Eocene to early Oligocene dinoflagellate assemblage, but Sample 119742A-34R-6, $116 \mathrm{~cm}$ (315 mbsf) from lithologic Subunit VIC bears only Late Cretaceous spores and pollen (B. Tocher, p. 415 in Barron, Larsen, et al., 1989; Truswell, this volume; Fig. 4). Although Truswell (this volume) assigns this basal sample to the Late Cretaceous, the sediments are obviously deformed (folded) and appear to have been emplaced either as a mass flow or as material rafted at the base of a moving glacier (Barron, Larsen, et al., 1989, p. 413). Interpretation of the magnetostratigraphy of this sequence (Barron et al., this volume; Figure 4) suggests a late middle Eocene age for this unit.

\section{Neogene Sediments}

Above the Paleogene glacial sediments, Neogene glacial sediments were recovered at Sites 739 and 742 (Figs. 4 and 5). At Site 739 diatoms suggest a late Quaternary age for Core 119739C-1R, an early Pliocene (diatom zone NSOD14-15; 4.6-3.6 Ma) age for Cores 119-739C-13R and 119-739C-14R and a late Miocene age for Cores 119-739C-18R through 119-739C-24R (ca. 7.4-6.6 Ma; Baldauf and Barron, this volume; Fig. 4).

The stratigraphic control at Site $\mathbf{7 4 2}$ is rather poor, with the exception of a 56-cm-thick diatomite recovered between 127.7 
and 128.3 mbsf which contains late Pliocene diatoms correlative with zone NSOD18 (2.22-1.89 Ma, Baldauf and Barron, this volume). This constrains the age of the overlying section to the latest Pliocene to Quaternary.

Logging Unit 2 of Barron, Larsen et al. (1989), which lies between 138.8 and 172.8 in Hole $742 \mathrm{~A}$, lacks microfossils, but logging and seismic stratigraphy suggests that it is equivalent to logging unit 2 of Site 739, which contains late Miocene and early Pliocene diatoms. These intervals in Hole $739 \mathrm{C}$ and Hole $742 \mathrm{~A}$ are relatively unique in terms of organic geochemistry in that they contain mature hydrocarbons (Mcdonald et al., this volume; Kvenvolden et al., this volume), further arguing for correlation. Thus, a tentative age of late Miocene to early Pliocene is inferred for the interval between 138.8 and 172.8 mbsf in Hole $742 \mathrm{~A}$ in Figure 5.

The poorly-recovered glacial diamictites in the upper $100 \mathrm{~m}$ of Hole 739C (Fig. 4) and in the upper $120 \mathrm{~m}$ of Hole $742 \mathrm{~A}$ (Fig. 5) are poorly constrained to the late Pliocene to Quaternary based on sparse and sporadic diatoms (Barron, Larsen, et al., 1989); however, a nearly complete Holocene record of interbedded siliceous ooze and diamictite is documented by Domack et al. (this volume) in the upper $23 \mathrm{~m}$ of inner Prydz Bay Hole $740 \mathrm{~A}$ based on the Accelerator Mass Spectrometer (AMS) dating of ${ }^{14} \mathrm{C}$ in organic matter.

\section{PALEOGENE GLACIAL HISTORY OF THE PRYDZ BAY REGION}

\section{Eocene Antarctic Glaciation}

As summarized in the following, Leg 119 studies from both Prydz Bay and the Kerguelen Plateau suggest the presence of glaciers in East Antarctica reaching sea level and advancing partly onto the shelf during at least parts of the late middle Eocene and the late Eocene (Table 4). Although the Prydz Bay shelf was most likely shallower prior to extensive grounding of ice on the shelf later in the Oligocene (Solheim et al., this volume), these supposed Eocene glaciers were probably more extensive than the limited alpine glaciers that Kennett (1978) envisioned for the Eocene of East Antarctica.

\section{Prydz Bay}

1. Seismic stratigraphy and logging suggest that a minimum of $300 \mathrm{~m}$ of glacial sediments was cored at Sites 739 and 742 beneath the lowermost Oligocene (36.0-34.8 Ma) glacial section sampled between 192.9 and 315.7 mbsf at Site 739 (Barron, Larsen, et al., 1989) (Figs. 3-5). Diatoms, calcareous nannofossils, and dinoflagellates indicate a general middle Eocene to early Oligocene age for this sequence. Within this time frame, a detailed magnetostratigraphy obtained from the lower part of this sequence in Hole 742A (172.5-316.0 mbsf; Sakai and Keating, this volume) correlates best with magnetic polarity Subchrons $\mathrm{C} 17 \mathrm{~N}-3$ through $\mathrm{C} 15 \mathrm{~N}-2$ and suggests an age of $40.8-37.46 \mathrm{Ma}$ for the lower part of this sequence (Barron et al., this volume).

2. Sediments from the basal $171 \mathrm{~m}$ of Hole $739 \mathrm{C}$ and the basal $143.5 \mathrm{~m}$ of Hole $742 \mathrm{~A}$ are interpreted as water-laid till and proximal glaciomarine sediments deposited in a prograding sequence in front of a grounded ice sheet (Hambrey et al., this volume). The rarity of biogenic material indicates proximity to the ice sheet and/or coverage of surface waters by sea ice. All diatoms identified from these intervals are marine.

3. Seismic stratigraphy suggests that glacial sediments may extend another $100 \mathrm{~m}$ below the base of Hole $742 \mathrm{~A}$ where a probable unconformity with preglacial sediments occurs (Cooper et al., this volume; A. K. Cooper, pers. comm., 1990).

4. Increased kaolinite concentrations $(<60 \%)$ in the lower sections of Holes $739 \mathrm{C}$ and $742 \mathrm{~A}$ and composition of organic matter suggests that the earliest stages of glaciation in Prydz
Bay eroded large quantities of soil and loose weathering products derived from both basement rocks and Permian and younger strata (Hambrey et al., this volume; Kvenvolden et al., this volume; Thierstein et al., this volume). The clay composition is thus slightly different from that of the upper prograding unit.

\section{Southern Kerguelen Plateau}

1. Isotopes. Detailed isotope studies at Site 744 range in age back to $39.4 \mathrm{Ma}$. Sparse data is available at Site 738 for the interval from 41.6 to $39.4 \mathrm{Ma}$, but no isotopic studies were completed for the interval between 45 and $41.6 \mathrm{Ma}$ by Barrera et al. (this volume). No major oxygen isotope enrichment events are observed in the upper middle Eocene to uppermost Eocene (45$36.6 \mathrm{Ma})$. A reduction in the stratification between intermediate (paleodepth $1800 \mathrm{~m}$ ) and near-surface waters is apparent between 39.0 and $35.6 \mathrm{Ma}$ (170.5 and $142.6 \mathrm{mbsf}$ ) at Site 744 (Barrera and Huber, this volume).

2. Ice-rafted detritus. Ehrmann (this volume) reports the earliest occurrences of possible in-situ gravel-sized, granitic material in Hole $738 \mathrm{C}$ in samples taken from 85 and 104 mbsf. Biostratigraphy suggests these samples have respective late middle Eocene ages of 42.0 and $43.4 \mathrm{Ma}$. The earliest detrital and grains, mainly angular to subangular quartz and felspar, are recorded by Ehrmann (this volume) from a depth of $131 \mathrm{mbsf}$ in Hole $738 \mathrm{C}$, an interval which is approximately $45.3 \mathrm{Ma}$ (middle Eocene) according to biostratigraphy (Barron et al., this volume). Additional terrigenous sand grains occur at 109 mbsf $(43.7 \mathrm{Ma})$ and 104 mbsf (43.4 Ma) according to Ehrmann, who argues that elevation of the southern Kerguelen Plateau of more than $2 \mathrm{~km}$ above the surrounding seafloor precludes transport from deep-sea basins, however, parts of the Kerguelen ridge were possibly emergent during the Eocene according to Cowell et al. (1988).

3. Clay minerals. At both Sites 738 and 744 concentrations of kaolinite show an initial three-fold increase at about $37.8 \mathrm{Ma}$ (35.85 mbsf at Site 738 and 159.06 mbsf at Site 744) indicating the possible appearance at these sites of kaolinite derived from glacial erosion of Antarctica (Ehrmann, this volume). A decline in smectite concentration from values $>88 \%$ to values between $78 \%$ and $60 \%$ begins at 38.73 mbsf (about $38.4 \mathrm{Ma}$ ) in Hole $738 \mathrm{~B}$ and at $167.0 \mathrm{mbsf}(38.7 \mathrm{Ma})$ in Hole 744A indicates a decline in moderately warm and humid climatic conditions in East Antarctica in which chemical weathering processes are prevalent according to Ehrmann (this volume). Minor inverse trends in chlorite and illite concentrations occur at the same intervals in Holes $738 \mathrm{~B}$ and $744 \mathrm{~A}$ suggesting cooler climates and enhanced physical weathering on the Antarctic continent (Ehrmann, this volume).

4. Biogenic opal. The onset of accumulation of biosiliceous components (although minor) occurs at $167 \mathrm{mbsf}(38.7 \mathrm{Ma})$ at Site 744 (Ehrmann, this volume). It should be noted, however, that opaline maxima ( $>8 \%$ of the bulk sediment) do occur in Cretaceous and middle Eocene sediments at Site 738 (Ehrmann, this volume).

\section{Major High-Latitude Cooling During the Later Part of the Eocene}

Oxygen isotope evidence supports major cooling of deep waters during the later part of the Eocene $(<45 \mathrm{Ma})$ (Shackleton, 1986; Miller et al., 1987); however, with the exception of Prentice and Matthews (1988), researchers have been reluctant to postulate the presence of significant ice on East Antarctica during this time.

Keigwin and Corliss (1986) record an enrichment in benthic foraminiferal oxygen isotopes of 1 per mil at DSDP Sites 19, 362 , and 363 from the South Atlantic across the middle/late Eocene boundary. Their studies on planktonic foraminifers across this 
boundary, however, are not detailed enough to establish whether planktonic foraminiferal $\delta^{18} \mathrm{O}$ also increased, which would be a sign of Antarctic ice sheet growth. Corliss and Keigwin (1986) stated that the benthic foraminiferal $\delta^{18} \mathrm{O}$ enrichment at the middle/late Eocene boundary reflects a deep-water cooling of the same or larger magnitude $\left(2^{\circ}-4^{\circ} \mathrm{C}\right)$ as that at the Eocene/ Oligocene boundary. They also point out that the timing of this cooling coincides with a dramatic decrease in abundance of the benthic foraminifer Nuttallides truempyi and the most significant Cenozoic change in the composition of deep-sea ostracodes (Benson, 1975), events which signal dramatic changes in the deep-sea environment.

Kennett and Stott's (1990) $\delta^{18} \mathrm{O}$ measurements of Cibicidoides at Maud Rise Site 689 include two steplike increases in the later part of the Eocene with no apparent reversals. An 0.5 per mil increase occurs between about 41.0 and $40.3 \mathrm{Ma}$ to values of about 1.5 per mil (Fig. 6) and an earlier increase of 0.3 per mil to values near 0.95 per mil is present between about 42.9 and 42.5 Ma. Kennett and Barker (1990) suggested that these two events each represent cooling of surface waters in the Weddell Sea of about $2^{\circ}-3^{\circ} \mathrm{C}$ but that average sea-surface temperatures of the Weddell Sea during the Eocene were never cooler than about $8^{\circ}-10^{\circ} \mathrm{C}$.
Prentice and Matthews (1988) argued for an ice volume increase between 42 and $40 \mathrm{Ma}$ based on parallel increases of at least 0.5 per mil in benthic and planktonic foraminiferal $\delta^{18} \mathrm{O}$ in their spliced record of the data of Oberhansli et al. (1984) and Murphy and Kennett (1986). Miller et al. (in press) suggest that the $41-40 \mathrm{Ma} \delta^{18} \mathrm{O}$ increase observed by Kennett and Stott (1990) does represent an ice growth event in East Antarctica based on the initiation of high rates of change of ${ }^{87} \mathrm{Sr} /{ }^{86} \mathrm{Sr}$ in the oceans at this time and on comparison with other oxygen isotope records.

\section{Major Ice Sheet in the Earliest Oligocene}

Evidence presented in this volume for the growth of a major ice sheet in the Prydz Bay region of East Antarctica during the earliest Oligocene and related major oceanographic changes at about $60^{\circ} \mathrm{S}$ on the southern part of the Kerguelen Plateau (Sites 738 and 744) is summarized as follows.

\section{Prydz Bay}

1. Massive and stratified glacial diamictites recovered from Cores 119-739C-27R through 119-739C-39R (192.9-315.7 mbsf) contain early Oligocene diatoms, calcareous nannofossils, and

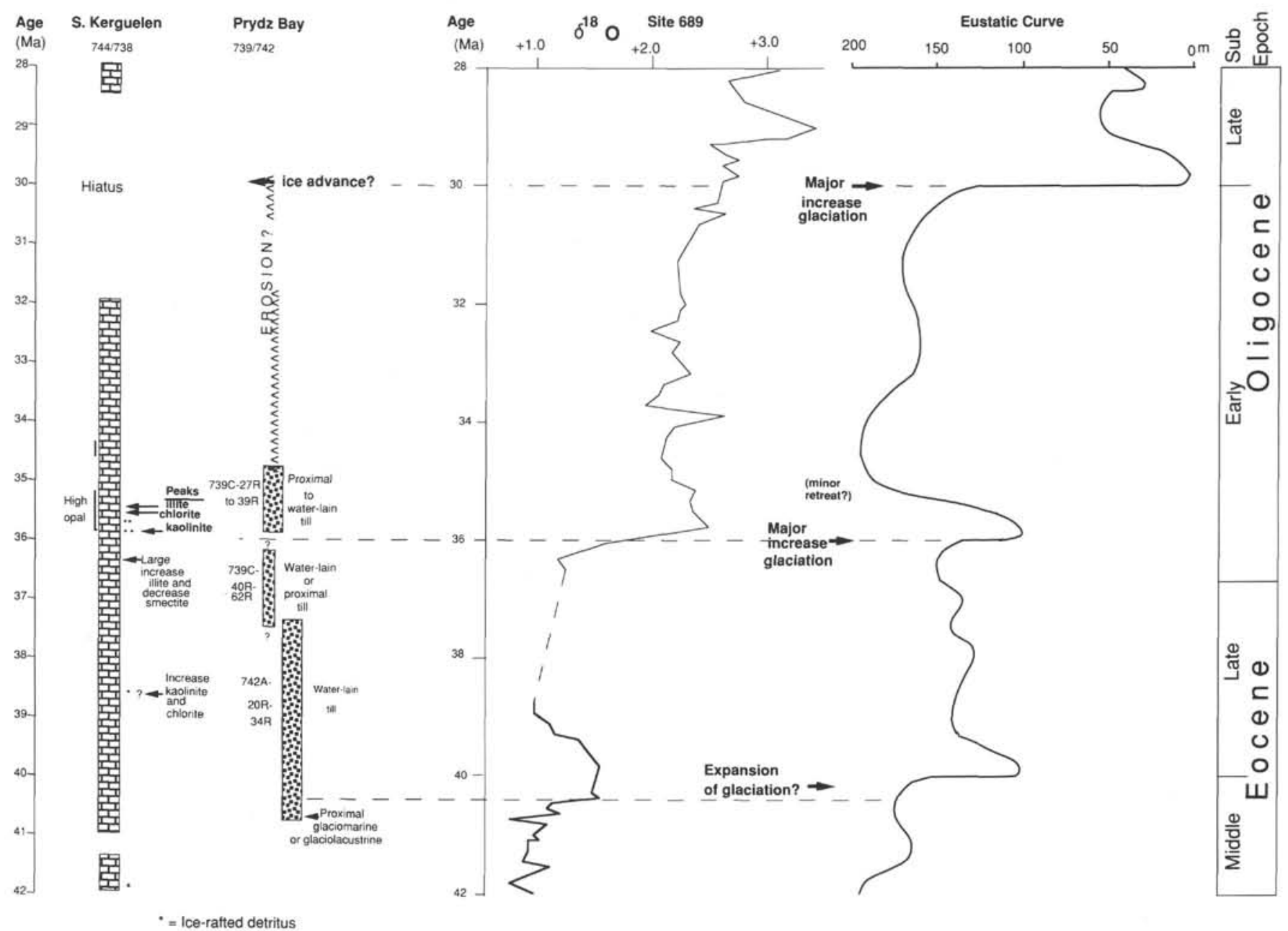

Figure 6. Comparison of the upper Paleogene sediment sequences recovered at Prydz Bay Sites 739 and 742 and southern Kerguelen Sites 744 and 738 with the benthic foraminiferal oxygen isotope record of Kennett and Stott (1990) from Maud Rise Site 689 and the eustatic curve of Haq et al. (1987) for the interval of 42-28 Ma. Three periods of expansion of East Antarctic glaciation at about 40.5, 36, and about 30 Ma are inferred. The eustatic curve is adjusted to the Berggren et al., (1985) time scale. 
dinoflagellates that suggest an age of $36.0-34.8 \mathrm{Ma}$ (Barron et al., this volume).

2. The depocenter for this approximately 122-m-thick sequence of glacial diamictite was on the upper continental slope (Hambrey et al., this volume; Cooper et al., this volume). This narrow zone of deposition is not consistent with the dispersal pattern of deposition from melting icebergs (ice rafting), but suggests a localized sediment source. This is provided by the melting of an ice sheet grounded to the shelf edge (Hambrey et al., this volume). The grounding line at the shelf edge would remain fixed, due to the abrupt increase in water depth seaward of that line, as long as ice production would be sufficient to cover the shelf (Thomas, 1979). The overconsolidation of the sediments proves the load of ice cover to the shelf break subsequent to the deposition of the prograding sediments (Solheim et al., this volume). Site 739 lies $140 \mathrm{~km}$ seaward to the present-day floating ice shelf, attesting to the large size of such an Oligocene ice sheet; however, the Prydz Bay shelf may have been shallower in the early Oligocene and the ice sheet more pancake-shaped than the present domed ice sheet.

\section{Southern Kerguelen Plateau}

1. Isotopes. The $\delta^{18} \mathrm{O}$ of the benthic foraminifer Cibicidoides increases 1.15 per mil at Site 744 between 36.5 and $35.8 \mathrm{Ma}$ (150 and $144 \mathrm{mbsf}$ ). During the remainder of the early Oligocene, $\delta^{18} \mathrm{O}$ values for Cibicidoides are relatively stable, between 2.7 and 2.5 per mil (Barrera and Huber, this volume).

2. Ice-rafted detritus. Unequivocal ice-rafted detritus in the form of quartz granules and manganese oxide-coated pebbles is documented between 36.0 and $35.9 \mathrm{Ma}$ (147.29 and 146.31 mbsf) by Ehrmann (this volume) at Site 744. Coarse terrigenous material begins at about $36.0 \mathrm{Ma}(19.98 \mathrm{mbsf})$ in Hole $738 \mathrm{~B}$ and extends upsection (Ehrmann, this volume). At ODP Site 748 (Leg $120,58^{\circ} 26.45^{\prime} \mathrm{S}, 78^{\circ} 58.89^{\prime} \mathrm{E}$, water depth $1298 \mathrm{~m}$ ) Breeza et al. (1988) and Schlich, Wise, et al. (1989) reported lowermost Oligocene ice-rafted detritus consisting of fine to coarse sand composed of feldspars and quartz between 115.47 and $115.84 \mathrm{mbsf}$ which they date between 35 and $36 \mathrm{Ma}$. Shipboard magnetostratigraphy suggests that this ice-rafted detritus peak lies near the base of 4-m-long interval of normal polarity which appears to be magnetic polarity Subchron C13N, according to shipboard biostratigraphy (Schlich, Wise, et al., 1989; Fig. 37). Such a correlation would suggest an age of approximately $35.9 \mathrm{Ma}$, coincident with that of the Site 744 ice-rafted detritus.

3. Clay minerals. Smectite concentrations drop from values of $70 \%$ or more to $16 \%$ between 36.4 and $35.7 \mathrm{Ma}$ (149 and 142 mbsf) at Site 744. Illite concentrations show an inverse trend rising from $21 \%$ to $67 \%$ between 35.9 and $35.7 \mathrm{Ma} \mathrm{(146.31}$ and $142 \mathrm{mbsf}$ ). This suggests a change in the Antarctic source area from moderately warm and humid climatic conditions dominated by chemical weathering processes to cooler climates and physical weathering. Above 142 mbsf smectite varies from about $25 \%$ to $50 \%$ and illite from about $60 \%$ to $35 \%$ for the remainder of the early Oligocene (Ehrmann, this volume).

4. Biogenic silica. An abrupt increase in the concentration of opaline matter (mostly diatoms and radiolarians) at Site 744 occurs at $35.9 \mathrm{Ma}(146.31 \mathrm{mbsf})$ where values less than $5 \%$ adjust to values of $10 \%-20 \%$, which persist until $35.7 \mathrm{Ma}(142.0$ mbsf) (Ehrmann, this volume). The onset of this increase in opal correlates with an abrupt decrease in carbonate concentration to $61.26 \%$ at $35.9 \mathrm{Ma}$ (146.31 mbsf), although carbonate concentrations immediately recover to values between $78 \%$ and $88 \%$ above that level (Ehrmann, this volume). Together, these data suggest an abrupt cooling of surface waters at Site 744 in the earliest Oligocene.
5. Microfossil assemblage changes. Cooling of the surface and intermediate waters over Site 738 during the earliest Oligocene is also revealed by the extinction of seven mostly warm to warm-temperate radiolarian taxa and their replacement by 18 Antarctic and temperate forms (Caulet, this volume). Although no upper Eocene diatomaceous sediments were recovered for comparison, early Oligocene diatom assemblages are typically subantarctic in character and warm to warm-temperate taxa such as Cestodiscus are relatively rare (Baldauf and Barron, this volume). Calcareous nannofossils and planktonic foraminifers assemblages show essentially permanent drops in diversity during the early Oligocene (from 16 to 18 species for calcareous nannofossils and from 14 to 8 species for planktonic foraminifers: Wei and Thierstein, this volume; Huber, this volume). Increased abundances of the benthic foraminifer Nuttalides umbonifera attest to the establishment of a cold, more carbonatecorrosive water mass over Site 744 (about $1800 \mathrm{~m}$ paleodepth) during the early Oligocene (Schröder-Adams, this volume).

6. Deep-sea hiatuses. In the composite Cenozoic section cored at Sites 738 and 744, deep-sea hiatuses become more numerous after the Eocene/Oligocene boundary. A hiatus at about $18 \mathrm{mbsf}$ in Hole $738 \mathrm{~B}$ spans the interval from 35 to $10 \mathrm{Ma}$ and may be coincident with increased circulation of Circumpolar Deep Water after $36 \mathrm{Ma}$ (Barron et al., this volume).

\section{Evidence for Mid-Oligocene Glaciation}

\section{Prydz Bay}

The stratigraphic interval between 167 and 173.6 mbsf in Hole $739 \mathrm{C}$ represents a hiatus spanning the interval from the early Oligocene (about $34.8 \mathrm{Ma}$ ) to the middle part of the late Miocene based on diatom biostratigraphy (Baldauf and Barron, this volume). Solheim (this volume) suggested that this unconformity actually occurs at about $192.6 \mathrm{mbsf}$ at the base of lithologic Subunit IIIA, which is characterized as a stratified diamictite representing post-depositional glaciotectonic deformation, according to Hambrey et al. (this volume).

Solheim et al. (this volume) performed consolidation tests on whole round core samples of glacigenic diamictites recovered at Prydz Bay Sites 739 and 742 in order to estimate consolidation stresses. The results of these experiments were used to estimate minimum past load, either as ice and/or eroded sediment thicknesses. Solheim et al.'s studies revealed that these glacial sediments showed high degrees of overconsolidation (that is, the sediments have been compressed by higher loads than the load of today as shown by their degree of compaction). Stepwise increases in the overconsolidation are observed, downcore at these Prydz Bay sites, are interpreted to represent periods of increased action of a grounded ice sheet covering the entire shelf. Based on theoretical ice sheet surface profiles, Solheim et al. (this volume) concluded that the combined load of the present overburden and the maximal theoretical ice thickness is not enough to explain the observed overconsolidation. Accordingly loading by sediments subsequently removed by erosion is also important for the overconsolidation.

Four separate, stepwise load events, each representing extensive periods of glaciation and glacial erosion across the continental shelf, are recognized downcore in Hole 739C by Solheim et al. (this volume). The lowermost event occurs between 228.0 and $186.1 \mathrm{mbsf}$ in Hole $739 \mathrm{C}$ in an interval dated as early Oligocene based on diatoms (Baldauf and Barron, this volume), late Eocene to early Oligocene based on calcareous nannofossils (Wei and Thierstein, this volume), and late Oligocene based on strontium isotopes (Thierstein et al., this volume; Fig. 4). This same event is assumed to occur between 182.50 and $204.32 \mathrm{mbsf}$ in Hole $742 \mathrm{~A}$ but biochronology is this interval is poor. Solheim 
et al. (this volume) equated this lowermost erosion event with the early Oligocene to late Miocene hiatus present in Hole $739 \mathrm{C}$, suggesting that the upper part of lithostratigraphic Subunit IIIA of Barron, Larsen, et al. (1989) represents reworked sediment associated with a glacial advance.

From the CIROS-1 drill hole in the Ross Sea, Barrett et al. (1989) reported major offshore growth of grounded glaciers at about $30.5 \mathrm{Ma}$ (middle part of the Oligocene) and a marked shallowing event which corresponds to a major drop in the eustatic sea level curve of Haq et al. (1987). Similarly, Bartek et al. (in press) suggested that the first major ice sheet grounding event in the Ross Sea during the late Oligocene was comparable in extent on the shelf with that of the Wisconsinian glacial maximum. It is tempting to suggest that such a late Oligocene period of growth of the East Antarctic ice sheet was responsible for both the erosion of sediments of this age from Site 739 and for loading event 1 of Solheim et al. (this volume).

\section{Southern Kerguelen Plateau}

The Site 744 sediment record contains a middle Oligocene hiatus spanning the interval between 32.0 and $28.5 \mathrm{Ma}$ (Barron et al., this volume). Keigwin and Keller (1984), Miller et al. (1987), and Kennett and Stott (in press) all recorded high benthic foraminiferal oxygen values ( $>1.8$ per mil) in the middle Oligocene interval from about 31 to $28 \mathrm{Ma}$, but this event is not present in the isotope record of Site 744 (Barrera and Huber, this volume). Similarly, a 25 - to $24-\mathrm{Ma}$ cooling event ( $>1.8$ per mil benthic foraminiferal oxygen isotope values) recorded by Miller et al. (1987) is not obvious in the Site 744 isotope record (Barrera and Huber, this volume), probably due to a 26.3- to 24.5-Ma hiatus that occurs at about 99 mbsf in Hole 744A (Barron et al., this volume).

\section{Summary of the Late Paleogene Glacial History of Prydz Bay}

Stages of development of late Paleogene glaciation in Prydz Bay are compared with the pelagic record at southern Kerguelen Sites 738 and 744 , the benthic foraminiferal oxygen isotope record of Kennett and Stott (1990) at Maud Rise Site 689, and the eustatic curve of Haq et al. (1987) in Figure 6. The Site 689 oxygen isotope data of Kennett and Stott (1990) are used rather than that of Barrera and Huber (this volume), because the data are more complete for the interval from 42 to $28 \mathrm{Ma}$.

The transition from a period of mixed glacial, fluvial, and lacustrine deposition on the inner shelf in Hole 742A to more intensified glacial conditions indicated by the deposition of water-laid glacial tills on the outer shelf occurs at about $40.7 \mathrm{Ma}$, coincides with a 0.5 per mil increase in the $\delta^{18} \mathrm{O}$ of Cibicidoides recorded by Kennett and Stott (1990), and approximates a major fall in sea level at about $40 \mathrm{Ma}$. An expansion of East Antarctic glaciation is inferred for this period of time.

A major expansion of East Antarctic glaciation occurred in the earliest Oligocene at $36 \mathrm{Ma}$, coinciding with a $>1$ per mil increase in benthic foraminiferal $\delta^{18} \mathrm{O}$ at Site 689 as well as at Site 744 (Barrera and Huber, this volume) and with a major fall in eustatic sea level (Fig. 6). An abrupt transition from gently dipping, poorly-fossiliferous glacial sediments to steeply dipping, fossiliferous glacial sediments at about 310 mbsf in Hole $739 \mathrm{C}$ took place at this time, seemingly at an unconformity caused by ice advance across Site 739 (Hambrey et al., this volume) (Table 4). At southern Kerguelen Site 744, a peak in icerafted detritus accumulation as well as maxima in illite, chlorite, and kaolinite concentrations occur at this time, and an increase in biogenic opal attests to cooling of the surface waters.

A major middle Oligocene increase in Antarctic glaciation, which is inferred at about $30 \mathrm{Ma}$ based on the global eustatic curve (Haq et al., 1987) and one or more increases in benthic fo- raminiferal $\delta^{18} \mathrm{O}$ (see Miller et al., 1987; in press), coincides with hiatuses at both Prydz Bay Site 739 and southern Kerguelen Site 744 (Fig. 6). Hambrey et al. (this volume) argued for an advance of the East Antarctic ice sheet across Site 739 to the shelf edge at this time based on the CIROS-1 borehole record in the Ross Sea, and Solheim et al. (this volume) suggest that erosion of sediment is indicated by an ice-loading event apparent in the physical properties of Site 739 sediments. Such evidence for a middle Oligocene expansion of the East Antarctic ice sheet in Prydz Bay, however, is indirect.

According to Hambrey et al. (this volume), the Paleogene glacial sediments of Prydz Bay compare more favorably with sandy temperate glacial sediments than with the modern polar glacial sediments of Antarctica in that they appear to be associated with higher amounts of meltwater. Hambrey et al. (this volume), however, argue that the thick, relatively uniform sequences of massive diamictites that typify the Paleogene glacial sediments of Prydz Bay indicate deposition close to a relatively stable grounding line of a floating glacier, and that sizable floating ice tongues are not known to be associated with modern temperate glaciers.

\section{NEOGENE GLACIAL HISTORY OF THE PRYDZ BAY REGION}

Periods of growth of the East Antarctic ice sheet proposed for the early Miocene (Barrett et al., 1989), middle Miocene (Barker et al., 1988), and early late Miocene (Ciesielski et al., 1982) coincide with the early Oligocene to late Miocene hiatus at Site 739 and conceivably could represent periods when ice was grounded across Site 739 and sediment was further eroded contributing to loading event 1 of Solheim et al. (this volume; Hambrey et al., this volume).

Any late Oligocene to early late Miocene ice advances across Site 739 would have deposited sediments seaward of the site beyond the seaward edge of the grounded ice sheet. Seismic stratigraphy of this outermost part of the shelf (Cooper et al., this volume) reveals numerous seaward-prograding glacial sequences that are post-early Oligocene in age and probably predate the flat-lying, compacted glacial diamictites of latest Miocene $(<7.4$ $\mathrm{Ma}$ ) and younger age recovered at Site 739 . Unfortunately, this area of the Prydz Bay shelf was not drilled on ODP Leg 119, so no direct evidence of any late Oligocene to early late Miocene ice advances was obtained.

\section{Glacial Loading Events}

The second glacial loading event recorded by Solheim et al. (this volume) at Site 739 occurs between 154.48 and 137.95 mbsf within or just above sediments dated as middle late Miocene (7.4-6.6 Ma) by diatoms (Baldauf and Barron, this volume; Fig. 4). This loading event may coincide with a latest Miocene (Messinian age) ice advance or series of ice advances occurring between about 6.2 and $4.8 \mathrm{Ma}$. Interestingly, Harwood et al. (1989b) report a middle late Miocene diatom assemblage in sediments immediately below the Ross Sea unconformity, which closely resembles the NSOD12 assemblage recovered in Cores $119-739 \mathrm{C}-18 \mathrm{R}$ to $119-739 \mathrm{C}-21 \mathrm{R}$, suggesting that glacial advances in the latest Miocene to Pleistocene have stripped off sediments and caused the unconformity.

Numerous isotope studies identify the latest Miocene as a period of significant growth of the Antarctic ice sheet. Hodell and Kennett (1986) reported high-frequency climatic fluctuation, and Keigwin's (1987b) high-resolution isotope study of North Atlantic DSDP Site 552 identifies two $\delta^{18} \mathrm{O}$ maxima at 5.2 and 4.7 $\mathrm{Ma}$, which he suggested result from Antarctic glaciations. The latest Miocene is proposed as the time of Solheim et al.'s (this volume) second glacial loading event. 
Solheim et al. (this volume) described a third loading event at both Sites 739 and 742 . At Site 739 this event is recorded between 107.3 and 117.6 mbsf (Cores 119-739C-13R to $119-739 C$ $14 \mathrm{R}$ ) within sediments dated as early Pliocene by diatoms (about 4.6-3.6 Ma; Baldauf and Barron, this volume; Fig. 4). This same event is identified between 113.5 and 142.8 mbsf in Hole $742 \mathrm{~A}$ (Fig. 5). Solheim et al. (this volume) suggested that this event probably coincides with the base of lithologic Unit III, a stratified diamictite containing sediment of a more distal glacial marine character than underlying Unit IV (Barron, Larsen, et al., 1989); this would place their loading event 3 at 134.4 mbsf in Hole 742A. Inasmuch as the 56-cm-thick diatomite in Core $119-742 \mathrm{~A}-14 \mathrm{R}$ contains diatoms assignable to zone NSOD 18 (1.89-2.22 Ma; Barron et al., this volume; Fig. 5), loading event 3 of Solheim et al. (this volume) may coincide with a major early late Pliocene period of ice sheet growth suggested at 2.5$2.4 \mathrm{Ma}$.

The youngest loading event reported by Solheim et al. (this volume) marks the transition from overconsolidated to normally consolidated sediment, which is placed at about 24 mbsf in Hole 739 C. It is likely that this event coincides with the last glacial maximum (latest Quaternary) when ice was grounded across Site 739 .

\section{Ice-Rafted Detritus Records}

Ehrmann (this volume) noted that coarse ice-rafted debris is virtually absent from the upper Oligocene to upper Miocene of Site 744 , but he argues that terrigenous debris in the silt-sized fraction is evidence of continuous ice rafting during this interval. A late Oligocene to early Miocene (27-23 Ma) decrease in coarse ice-rafted detritus was also noted in the mudstone units of the CIROS-1 drill hole in the Ross Sea (Barrett et al., 1989).

Ehrmann (this volume) recorded a return of ice-rafted gravel and sand beginning at about $9 \mathrm{Ma}$ at Site 744 that persists until the present. At Sites 745 and 746, Ehrmann et al. (this volume) note peaks in ice-rafted detritus between 8.4 and 7.6, 6.6 and $6.0,5.0$ and 4.4 , and 4.0 and $3.2 \mathrm{Ma}$ (ages updated according to the biochronology of Barron et al., this volume). During more recent times, they report less pronounced peaks in ice-rafted detritus between 2.4 and $1.6 \mathrm{Ma}$ and between 1.4 and $1.0 \mathrm{Ma}$. The relatively higher amounts of ice-rafted detritus in the late Miocene to early Pliocene were attributed by Ehrmann et al. (this volume) to relatively warmer conditions during these times with repeated advances and retreats of ice, compared with a cooler late Pliocene to Quaternary interval that promoted more stable ice shelves.

At DSDP Sites $513\left(47^{\circ} 34.99^{\prime} \mathrm{S}, 24^{\circ} 38.40^{\prime} \mathrm{W}\right.$, water depth $4373 \mathrm{~m})$ and $514\left(46^{\circ} 02.769^{\prime} \mathrm{S}, 26^{\circ} 51.29^{\prime} \mathrm{W}\right.$, water depth 4318 $\mathrm{m})$ in the Atlantic sector of the Southern Ocean Bornhold (1983) noted peaks in ice-rafted detritus abundance at 6.7-6.5, $5.46,4.1-3.86,2.69-2.58,2.1-1.8,1.5-0.97,0.90-0.65 \mathrm{Ma}$, and during the last $400,000 \mathrm{yr}$. Assignment of the ages prior to 3 $\mathrm{Ma}$, however, is somewhat questionable, because it is based on diatom biochronology of Ciesielski (1983) which has undergone changes since the publication in 1983 of DSDP Volume 71 (Baldauf and Barron, this volume).

\section{Summary of the Neogene Glacial History}

Figure 7 compares periods of ice-rafted detritus accumulation in Kerguelen Sites 744 through 746 with the ages of Neogene glacial sediments recovered in Prydz Bay and the pelagic sediment record at northern Kerguelen Sites 736 and 737. Biostratigraphy, strontium isotope stratigraphy, and magnetostratigraphy (Barron et al., this volume) reveals that these sedimentary sequences are interrupted by numerous hiatuses (Table 5). These data are also correlated with a spliced benthic foraminiferal oxygen isotope curve from Sites 588 and 590 for the middle
Miocene and Pliocene and to the Haq et al. (1987) eustatic curve for the last $15 \mathrm{~m} . \mathrm{y}$.

The oxygen isotope data used in Figure 7 is that of Kennett (1986) for the benthic foraminifer Cibicidoides at DSDP Sites $588\left(26^{\circ} 06.7^{\prime} \mathrm{S}, 161^{\circ} 13.6^{\prime} \mathrm{E}\right.$, water depth $\left.1533 \mathrm{~m}\right)$ and 590 $\left(31^{\circ} 10.02^{\prime} \mathrm{S}, 163^{\circ} 21.51^{\prime} \mathrm{E}\right.$, water depth $\left.1299 \mathrm{~m}\right)$ in the southwestern Pacific. The isotope record for Site 588 is one of the most detailed records available and is directly calibrated to the magnetostratigraphic record back to $13 \mathrm{Ma}$ (Barton and Bloemendal, 1986). The chronology of the Site 588 oxygen isotope curve (interval from 15.0 to $4.25 \mathrm{Ma}$ ) has been updated according to this magnetostratigraphy and the Neogene biochronologic time scale of Barron et al. (1985) and correlated with the Neogene Southern Ocean biochronologic time scale (Barron et al., this volume) used for Leg 119 studies. Oxygen isotope data for the interval from 4.18 to $1.81 \mathrm{Ma}$ of Site 590 (ages from Kennett, 1986) have been spliced onto the Site 588 curve.

General periods of high-latitude cooling and/or ice growth are apparent from the Site 588 and 590 isotope curve of Figure 7. The period of major middle Miocene cooling began at about $15 \mathrm{Ma}$ and continued to $12.4 \mathrm{Ma}$. During this interval, benthic oxygen isotope values increased by more than 1.0 per mil, signalling major growth of the East Antarctic ice sheet and highlatitude cooling according to Kennett (1986). Cooling continued by a series of steps, interrupted by short reversals or warming trends, into the late Miocene. The interval from 11.5 to $10.4 \mathrm{Ma}$ represents one such reversal or "warm interval" during the latest middle Miocene. Two periods of cooling follow between 10.3 and $9.2 \mathrm{Ma}(+0.5$ per mil increase) and between 9.0 and $8.3 \mathrm{Ma}$ ( +0.4 per mil increase), and were succeeded, in turn, by a third reversal or warm interval between 7.6 and $6.6 \mathrm{Ma}$. During this third warm interval, oxygen isotope values at Site 588 were depleted by $0.3-0.4$ per mil compared to those of the immediately proceeding interval of the early late Miocene. The latest Miocene to earliest Pliocene (6.2-4.8 Ma) was generally cool (Fig. 7 ), but it was marked by considerable high frequency climatic fluctuation (Hodell and Kennett, 1986). Keigwin's (1987b) highresolution isotope study of the uppermost Miocene of North Atlantic Site 552 identified two maxima at 5.2 and $4.8 \mathrm{Ma}$ which most likely correlate with the maxima of the Site 588 record that are plotted at 5.3 and $5.1 \mathrm{Ma}$ on Figure 7..Hodell and Kennett (1986) suggested that the early Pliocene of Site 588 corresponds to a prolonged period of deglaciation between about 5.0 and 4.1 Ma, but Figure 7 and the results of Elmstrom and Kennett (1986) would suggest that these warmer conditions actually began about $4.8 \mathrm{Ma}$ and extended to about $3.6 \mathrm{Ma}$. The late Pliocene is characterized by a general cooling trend and large-scale fluctuations.

Detailed late Pliocene records, such as those of Keigwin (1987a), Sarnthein and Tiedemann (1989), and Raymo et al. (1989), call for increased glacial-interglacial variation beginning at $2.4 \mathrm{Ma}$ with additional $\delta^{18} \mathrm{O}$ enrichment events at 2.6, 2.7, and 3.1 Ma. The variation of these records is too detailed to include on Figure 7 and is beyond the resolution of biostratigraphy of the Prydz Bay and Kerguelen sediments.

From Figure 7 it appears that the upper Miocene and lower Pliocene glacial sediments recovered from Hole $739 \mathrm{C}$ correspond to relatively warmer paleoclimates and higher stands of sea level. Presumably, these sediments were deposited on the Prydz Bay shelf during a retreat phase of the East Antarctic ice sheet. It is not obvious, however, to what degree these retreat phases represent deglaciation on a scale such as that envisioned by Webb et al. (1984) (Hambrey et al., this volume).

In the Vestfold Hills east of Prydz Bay, Pickard (1986) reports lower Pliocene glaciomarine sediments which are currently $15 \mathrm{~m}$ above sea level containing abundant diatoms and mollusks. Pickard et al. (1988) inferred that the coastline and ice 


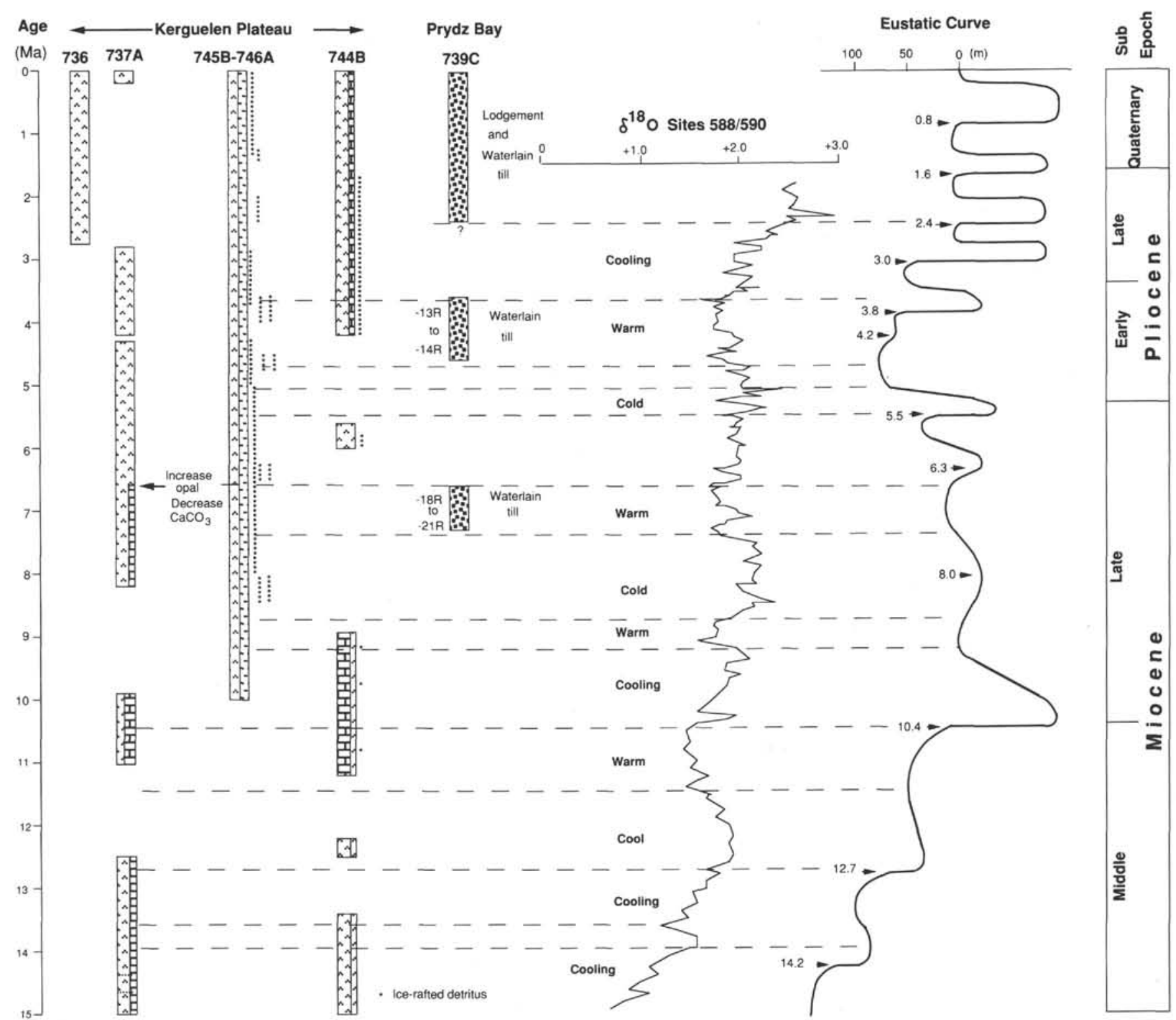

Figure 7. Comparison of the upper Neogene sediment record at Prydz Bay Site 739, southern Kerguelen Sites 744, 745, and 746, and northern Kerguelen Sites 736 and 737 with the spliced benthic foraminiferal oxygen isotope record of Sites 588 and 590 (southwest Pacific) of Kennett (1986) and the eustatic curve of Haq et al. 1987). Periods of relative cooling and warming (and/or waxing and waning of the Antarctic Ice Sheet) are inferred. The eustatic curve is adjusted to the Berggren et al., (1985) time scale.

margin were as much as $50 \mathrm{~km}$ farther inland during the time of deposition of these sediments. Diatom biostratigraphy constrains these Vestfold Hills deposits to about 4.5-3.5 Ma (Pickard et al., 1988), an age correlative with the early Pliocene diatom assemblages of Cores $119-739 \mathrm{C}-13 \mathrm{R}$ and $119-739 \mathrm{C}-14 \mathrm{R}$ (4.6-3.6 Ma) of Site 739 .

Additional evidence for surface-water warming at about 4.14.2 Ma comes from the presence of abundant calcareous nannofossil assemblages in sediments of this age at both southern Kerguelen Site 744 and northern Kerguelen Site 737 (Wei and Thierstein, this volume; Table 6). Figure 7 also reveals that the peaks in ice-rafted detritus accumulation identified by Ehrmann et al. (this volume) at Sites 745 and 746 generally correspond to rela- tively cooler periods. Peak ice-rafted detritus accumulation between 5.0 and 4.4 and 4.0 and $3.2 \mathrm{Ma}$, however, embrace a generally warmer interval of time between 4.8 and about $3.6 \mathrm{Ma}$, according to Figure 6.

Of particular interest is the transition in the diatom assemblage at Site 737 from warm and warm-temperate to temperate species between 4.8 and 4.2 Ma. During this time interval, species characteristic and endemic to the Southern Ocean increase in abundance at the expense of species with geographically widespread distribution. The timing of this transition corresponds in part to an decrease in $\delta^{18} \mathrm{O}$ values suggesting that the increased endemism of the diatom flora corresponds to generally warmer, not cooler, conditions and may relate to increase development 
Table 5. Hiatuses in Leg 119 Sections.

\begin{tabular}{cccc}
\hline Site & Hole & $\begin{array}{c}\text { Depth } \\
\text { (mbsf) }\end{array}$ & $\begin{array}{c}\text { Duration } \\
\text { (m.y.) }\end{array}$ \\
\hline 737 & $737 \mathrm{~A}$ & 1.5 & $\begin{array}{c}0.2-2.8 \\
\text { Ma }\end{array}$ \\
& & & $4.2-4.3 ?$ \\
& $737 \mathrm{~A}$ & 66 & $8.2-9.9$ \\
& $737 \mathrm{~B}$ & 263 & $11.0-12.5$ \\
& $737 \mathrm{~B}$ & 285 & $15->25.5$ \\
& $737 \mathrm{~B}$ & 312.8 & $38.3-41.0$ \\
& $737 \mathrm{~B}$ & 655 & $>8.4-6.0$ \\
738 & $738 \mathrm{~B}$ & 16.75 & $9.9-\mathrm{ca}$. \\
& $738 \mathrm{~B}$ & 18 & 35.0 \\
& & & $41.0-41.4$ \\
& $738 \mathrm{~B}$ & 71 & $70.5-68.0$ \\
& $738 \mathrm{C}$ & 410 & $<7.4-34.8$ \\
739 & $739 \mathrm{C}$ & 172 (or 190$)$ & $4.2-5.6$ \\
& & & $6.0-8.9$ \\
744 & $744 \mathrm{~B}$ & 22 & $11.2-12.2$ \\
& $744 \mathrm{~B}$ & 24 & $12.5-13.4$ \\
& $744 \mathrm{~B}$ & 53 & $21.3-24$ \\
& $744 \mathrm{~B}$ & 55 & $24.5-26.3$ \\
& $744 \mathrm{~A}$ & 97 & $28.5-32.0$ \\
& $744 \mathrm{~A}$ & 99 & \\
& $744 \mathrm{~A}$ & 118 & \\
& & &
\end{tabular}

Note: Sites $740-743$ have biochronologies too poor to resolve the ages of any potential hiatuses. Sites $736,745,746$ had no hiatuses detected.

Table 6. Occurrence of abundant to common nannofossils.

\begin{tabular}{|c|c|c|c|}
\hline $\begin{array}{c}\text { Site } \\
\text { or hole }\end{array}$ & $\begin{array}{l}\text { Water depth } \\
\text { (m) }\end{array}$ & $\begin{array}{l}\text { Interval } \\
\text { (mbsf) }\end{array}$ & $\begin{array}{c}\text { Interval } \\
\text { (Ma) }\end{array}$ \\
\hline 737 & 564 & $\begin{array}{l}80.85-81.0 \\
>236.5\end{array}$ & $\begin{aligned} & 4.26 \\
> & 6.8\end{aligned}$ \\
\hline 738 & 2253 & $>16.7$ & $>5.9$ \\
\hline 739 & 412 & 57.6 & ? \\
\hline $744 \mathrm{~B}$ & 2307 & $\begin{array}{l}20.96-21.23 \\
>23.4\end{array}$ & $\begin{array}{l}4.1-4.2 \\
>5.9\end{array}$ \\
\hline 746 & 4059 & 245.06 & 9.0 \\
\hline
\end{tabular}

of the Antarctic Polar Front and increased volume of northern source deep water in the vicinity of Site 737 during the early Pliocene.

A transition from mixed calcareous-biosiliceous ooze to essentially pure biosiliceous ooze which occurs at about $230 \mathrm{mbsf}$ in northern Kerguelen Site 737, corresponds to a time of about 6.7 Ma (Barron et al., this volume) and coincides with the onset of generally cooler high-latitude surface water temperatures according to the Site 588 and 590 isotope curve (Fig. 7). This transition occurs immediately above an 8.9-6.0 Ma hiatus at southern Kerguelen Site 744 (Fig. 7) and at a similar latest Miocene time in the central part of the Kerguelen Plateau (Schlich, Wise, et al., 1989).

At Radok Lake, in the northern Prince Charles mountains southwest of Prydz Bay, McKelvey and Stephenson (1990) report that an irregular blanket of the Pagodroma Tillite, up to $100 \mathrm{~m}$ thick, overlies Permian strata and Proterozoic basement at elevations 400 to $1300 \mathrm{~m}$ above present sea level. D. M. Harwood (in McKelvey and Stephenson, 1990) reports the presence of both reworked upper Miocene and a middle Pliocene diatom floras in the Pagodroma Tillite, and he assigns an age of no older than $3.5 \mathrm{Ma}$, or roughly contemporaneous with the Sirius Group of the Transantarctic Mountains. McKelvey and Stephenson (1990) argue that if the contemporaneity of the Pagodroma Tillite and the Sirius Group is assumed, a major expansion of the East Antarctic Ice Sheet in the late Pliocene or early Pleistocene must have occurred. Presumably, loading event 3 of Solheim et al. (this volume), which was recorded in glacial sediments at Site 739 (between 107.3 and $117.6 \mathrm{mbsf}$ ) and Site 742 (between 113.5 and $142.8 \mathrm{mbsf}$ ), may record this same late Pliocene to early Pleistocene expansion of the East Antarctic Ice Sheet.

\section{CONCLUSIONS}

Leg 119 recovered sediments from 11 sites from the Kerguelen Plateau, in the Indian sector of the Southern Ocean, and from Prydz Bay, East Antarctica. The occurrence of well-dated, lowermost Oligocene diamictites at Site 739 and an additional $300 \mathrm{~m}$ of diamictite beneath that sequence attest to the presence of an extensive ice sheet in East Antarctica during the earliest Oligocene. Diamictites from the lower $140 \mathrm{~m}$ of Hole 742A, which are dated as middle Eocene to earliest Oligocene by biostratigraphy and superposition, yield a distinctive magnetostratigraphy that correlates well with the latest middle Eocene to late Eocene interval of Subchron C17N-3 (40.8 Ma) to Subchron C15N-2 (37.46 Ma), implying that glaciers in Prydz Bay reached sea level during at least parts of the late middle Eocene and the late Eocene.

An early Oligocene to late Miocene hiatus at Site 739 precludes the interpretation of the Prydz Bay glacial record during this period of time; however, overconsolidated sediments associated with this unconformity are taken as evidence of one or more advances of ice to the shelf edge.

Diatom-rich sediments are preserved in the Prydz Bay glacial sequence during apparent interglacial intervals or periods of ice sheet retreat in the late Miocene (7.4-6.6 Ma), early Pliocene (4.6-3.6 Ma), and late Pliocene (2.22-1.89 Ma). The early Pliocene interval is equivalent in age to a major early Pliocene deglaciation event proposed by Harwood (1986b; 1987) and Harwood and Webb (1990) based on the presence of diatoms of this age in both the Sirius Group of the Transantarctic Mountains and in Pagodroma Tillite of the Prince Charles Mountains west of Prydz Bay. Harwood reasons that these early Pliocene marine diatoms of the Sirius Group and the Pagodroma Tillite are recycled from interior Antarctic basins which were open seaways during the early Pliocene.

Most upper Pliocene to Quaternary sediments recovered in Prydz Bay are fossil-poor and strongly glacial in character, and little detail of the late Pliocene to Quaternary glacial history of Prydz Bay can be elucidated. Domack et al. (this volume), however, document a detailed Holocene history of inner Prydz Bay Site 740 based on AMS dating of ${ }^{14} \mathrm{C}$. They show that open marine conditions began at Site 740 about 10,700 yr ago, resumption of terrigenous sedimentation and possible readvance of floating ice tongues across the site characterized the interval between 7300 and $3800 \mathrm{yr}$ ago, and that open marine conditions with seasonal sea ice have typified the last $3800 \mathrm{yr}$.

Although major gaps are present in the middle and late $\mathrm{Ce}-$ nozoic history of Antarctic glaciation provided by Leg 119 studies, available data and interpretations support parts of the hypotheses for Cenozoic Antarctic glacial history proposed by both Miller et al. (1987) and Barrett et al. (1989), namely, (1) that a major, continental-sized ice sheet was present on East Antarctica in the earliest Oligocene; (2) that this earliest Oligocene ice sheet was likely temperate in character; and (3) that subsequent growth and decay events of ice sheets certainly occurred during the late Neogene and possibly also during the late Oligocene to middle Miocene based on the presence of numerous, undrilled sediment wedges of glacial sediments located seaward of Site 739 (Fig. 3). Some support for an early Pliocene deglaciation event proposed by Harwood $(1986 \mathrm{~b}, 1987)$ and Harwood and Webb (1990) is provided by the recovery of diatoms of this age (4.6-3.6 Ma) in distal glaciomarine sediments at Site 
739 , but the duration and extent of such an early Pliocene deglaciation cannot be judged from Leg 119 data.

\section{ACKNOWLEDGMENTS}

We thank John Anderson, Louis Bartek, David Harwood, Alan Cooper, and James Kennett for discussion. Michael Prentice, David Harwood, Louis Bartek, Lloyd Burckle, and James Kennett were kind enough to send us unpublished manuscripts. This manuscript benefitted greatly from the reviews of John Anderson, David Harwood, James Kennett, and Michael Hambrey. The Danish Natural Science Research Council and U.S. Science Advisory Council are thanked for financial support.

\section{REFERENCES}

Ackley, S. F., 1979. Mass balance aspects of Weddell Sea pack ice. $J$. Glaciol., 24:391-405.

Anderson, J. B., 1986. Critical evaluation of some criteria used to infer Antarctica's glacial and climatic history from deep-sea sediments. $S$. Afr. J. Sci., 82:503-505.

1989. Glacial erosion of the Antarctic continental shelf: impact on ice sheet development, bottom water production, and glacial eustasy. Geol. Soc. Am. Abstr. Programs, 21.

Anderson, J. B., Brake, C., Domack, E., Myers, N., and Wright, R., 1983. Development of a polar glacial-marine sedimentation model from Antarctic Quaternary deposits and glaciological information. In Molnia, B. F. (Ed.), Glacial-Marine Sedimentation: New York (Plenum Press), 233-264.

Anderson, J. B., Kurtz, D. D., Domack, E. W., and Balshaw, K. M., 1980. Glacial and glacial marine sediments of the Antarctic continental shelf. J. Geol., 88:399-414.

Baldauf, J. G., and Barron, J. A., 1990. Evolution of biosiliceous sedimentation patterns for the Eocene through Quaternary: Paleoceanographic response to polar cooling. In Bleil, U., and Thiede, J. (Ed.), Geologic History of the Polar Oceans: Arctic versus Antarctic. NATO ASI Ser., Dordrecht (Kluwer Academic Publ.), 575-607.

Barker, P. F., Kennett, J. P., and Leg 113 Shipboard Scientific Party, 1988. Weddell Sea palaeoceanography: preliminary results of ODP Leg 113. Palaeogeogr., Palaeoclimatol., Palaeoecol., 67:75-102.

Barrett, P. J. (Ed.), 1986. Antarctic Cenozoic history from the MSSTS-1 drillhole, McMurdo Sound. DSIR Bull., 237.

Barrett, P. J., Elston, D. P., Harwood, D. M., McKelvey, B. C., and Webb, P. N., 1987. Mid-Cenozoic record of glaciation and sea level change on the margin of the Victoria Land Basin, Antarctica. Geology, 15:634-637.

Barrett, P. J., Hambrey, M. J., Harwood, D. M., Pyne, A. R., and Webb, P.-N., 1989. Synthesis. In Barrett, P. J. (Ed.), Antarctic Cenozoic History from the CIROS-1 Drillhole, McMurdo Sound: DSIR Bull., 245:241-251.

Barron, J. A., Keller, G., and Dunn, D. A., 1985. A multiple microfossil biochronology for the Miocene. In Kennett, J. P. (Ed.), The Miocene Ocean: Paleoceanography and Biogeography. Mem. Geol. Soc. Am., 163:21-36.

Barron, J., Larsen, B., et al., 1989. Proc. ODP, Init. Repts., 119: College Station, TX (Ocean Drilling Program).

Bartek, L. R., III, 1989. Sedimentology and stratigraphy of McMurdo Sound and the Ross Sea, Antarctica: implications for glacial history and analysis of high latitude marginal basins [Ph.D. dissert]. Rice Univ., Houston, TX.

Bartek, L. R., Vail, P. R., Anderson, J. B., Emmet, P. A., and Wu, S., in press. The effect of Cenozoic ice sheet fluctuations in Antarctica on the stratigraphic signature of the Neogene. J. Geophys. Res.

Barton, C. E., and Bloemendal, J., 1986. Paleomagnetism of sediments collected during Leg 90, Southwest Pacific. In Kennett, J. P., von der Borch, C. C., et al., Init. Repts. DSDP, 90: Washington (U.S. Govt. Printing Office), 1273-1316.

Benson, R. H., 1975. The origin of the psychrosphere as recorded in changes of deep sea ostracode assemblages. Lethaia, 8:69-83.

Berggren, W. A., Kent, D. V., Flynn, J. J., and Van Couvering, J. A., 1985. Cenozoic geochronology. Geol. Soc. Am. Bull., 96:14071418.

Birkenmajer, K., 1988. Tertiary glacial and interglacial deposits, South Shetland Islands, Antarctica: geochronology versus biostratigraphy (a progress report). Bull. Pol. Acad. Sci. Earth Sci., 36:133-144.
Bornhold, B. D., 1983. Ice-rafted debris in sediments from Leg 71, southwest Atlantic Ocean. In Ludwig, W. J., Krasheninnikov, V. A., et al., Init. Repts. DSDP, 71: Washington (U.S. Govt. Printing Office), 307-316.

Breeza, J. R., Wise, S. W., and Ocean Drilling Program Leg 120 Shipboard Scientific Party, 1988. Lower Oligocene ice-rafted debris on the central Kerguelen Plateau, ODP Leg 120: evidence for East Antarctica continental glaciation. Geol. Soc. Am. Abstr. Programs, 20: A69.

Broecker, W. S., and Peng, T.-H., 1982. Tracers in the Sea: Palisades, NY (Eldigio Press).

Burckle, L. H., 1984. Diatom distribution and palaeoceanographic reconstruction in the Southern Ocean-present and Last Glacial Maximum. Mar. Micropaleontol., 9:241-261.

Burckle, L. H., and Abrams, N., 1987. Regional late Pliocene-early Pleistocene hiatuses of the Southern Ocean-diatom evidence. Mar. Geol., 77:207-218.

Ciesielski, P. F., 1983. The Neogene and Quaternary diatom biostratigraphy of subantarctic sediments, Deep Sea Drilling Project Leg 71. In Ludwig, W. J., Krasheninnikov, V. A., et al., Init. Repts. DSDP, 71 (Pt. 2): Washington (U.S. Govt. Printing Office), 635-666.

Ciesielski, P. F., Ledbetter, M. T., and Ellwood, B. B., 1982. The development of Antarctic glaciation and the Neogene paleoenvironment of the Maurice Ewing Bank. Mar. Geol., 46:1-51.

Ciesielski, P. F., and Weaver, F. M., 1983. Neogene and Quaternary paleoenvironmental history of Deep Sea Drilling Project Leg 71 sediments, southwest Atlantic Ocean. In Ludwig, W. J., Krasheninnikov, V. A., et al., Init. Repts. DSDP, 71 (Pt. 1): Washington (U.S. Govt. Printing Office), 461-477.

Corliss, B. H., and Keigwin, L. D., 1986. Eocene-Oligocene paleoceanography. In Hsü, K. J. (Ed.), Mesozoic and Cenozoic Oceans. Am. Geophys. Union Geodyn. Ser., 15:101-118.

Cowell, J. B., Coffin, M. F., Pigram, C. J., Davies, H. L., Stagg, H.M.J., and Hill, P. J., 1988. Seismic stratigraphy and evolution of the Raggatt Basin, southern Kerguelen Plateau, Mar. Pet. Geol., 5: $75-81$.

Denton, G. H., Prentice, M. L., and Burckle, L. H., in press. Cenozoic history of the Antarctic Ice Sheet. In Tingey, R. (Ed.), Antarctic Earth Science: Oxford (Oxford Univ. Press).

DePaolo, D. J., and Ingram, B. L., 1985. High-resolution stratigraphy with strontium isotopes. Science, 227:938-940.

Drewry, D. J., and Cooper, A.P.R., 1981. Processes and models of Antarctic glaciomarine sedimentation. Ann. Glaciol., 2:117-122.

Elmstrom, K., and Kennett, J. P., 1985. Late Neogene paleoceanographic evolution of Site 590: southwest Pacific. In Kennett, J. P., von der Borch, C. C., et al., Init. Repts. DSDP, 90 (Pt. 2): Washington (U.S. Govt. Printing Office), 1361-1383.

Flint, R. F., 1971. Glacial and Quaternary Geology: New York (Wiley).

Foldvik, A., and Gammelsrød, T., 1988. Notes on Southern Ocean hydrography, sea-ice and bottom water formation. Palaeogeogr., Palaeoclimatol., Palaeoecol., 67:3-17.

Foster, T. D., and Carmack, E. C., 1976. Frontal zone mixing and Antarctic Bottom Water formation in the southern Weddell Sea. DeepSea Res. Oceanogr. Abstr., 23:307-317.

Gordon, A. L., 1971. Oceanography of Antarctic waters. In Reid, J. L. (Ed.), Antarctic Oceanology I. Am. Geophys. Union, Antarct. Res. Ser., 15:169-203.

Hambrey, M. J., Larsen, B., Ehrmann, W. U., and ODP Leg 119 Shipboard Scientific Party, 1989. Forty million years of Antarctic glacial history yielded by Leg 119 of the Ocean Drilling Program. Polar Rec., 25:99-106.

Haq, B. U., 1980. Biogeographic history of Miocene calcareous nannoplankton and paleoceanography of the Atlantic Ocean. Micropaleontology, 26:414-443.

Haq, B. U., Hardenbol, J., and Vail, P. R., 1987. Chronology of fluctuating sea levels since the Triassic. Science, 235:1156-1167.

Harwood, D. M., 1986a. Diatoms. In Barrett, P. J. (Ed.), Antarctic Cenozoic History from the MSSTS-I Drillhole, McMurdo Sound. DSIR Bull. N. Z., 237:69-107.

1986b. Recycled siliceous microfossils from the Sirius Formation. Antarctic J. U.S., 21:101-103.

1987. Cenozoic Antarctic temperature, ice-volume and bottom water events: a comparison of Sirius Formation microfossil data to eustatic and oxygen isotope data. Geol. Soc. Am. Annu. Mtg., Abstr. with Program, 19:695. 
1989. Siliceous microfossils. In Barrett, P. J. (Ed.), Antarctic Cenozoic History from the CIROS-1 Drillhole, McMurdo Sound. DSIR Bull. N. Z., 245:67-97.

Harwood, D. M., Barrett, P. J., Edwards, A. R., Rieck, H. J., and Webb, P.-N., 1989a. Biostratigraphy and chronology. In Barrett, P. J. (Ed.), Antarctic Cenozoic History from the CIROS-1 Drillhole, McMurdo Sound. DSIR Bull. N. Z., 245:231-239.

Harwood, D. M., Scherer, R. P., and Webb, P.-N., 1989b. Multiple Miocene marine productivity events in West Antarctica as recorded in upper Miocene sediments beneath the Ross Ice Shelf (Site J-9). Mar. Micropaleontol., 15:91-115.

Harwood, D. M., and Webb, P.-N., 1990. Early Pliocene deglaciation of the Antarctic Ice Sheet and late Pliocene onset of bipolar glaciation. Eos, 71:538.

Harwood, D. M., Webb, P.-N., and Barrett, P. J., 1989. Multiple Cenozoic glaciations of Antarctica from terrestrial and continental shelf data. Abstr. Third Inter. Conf. on Palaeoceanography, Oxford (Blackwell Sci.), 2.

Hayes, D. E., Frakes, L. A., et al., 1975. Init. Repts. DSDP, 28: Washington (U.S. Govt. Printing Office).

Hill, R. S., 1989. Fossil leaf. In Barrett, P. J. (Ed.), Antarctic Cenozoic History from the CIROS-1 Drillhole, McMurdo Sound: DSIR Bull., 245:143-144.

Hodell, D. A., and Kennett, J. P., 1986. Late Miocene-early Pliocene stratigraphy and paleoceanography of the South Atlantic and southwest Pacific Oceans: a synthesis. Paleoceanography, 1:285-311.

Keigwin, L. D., 1986. Pliocene stable-isotope record of Deep Sea Drilling Project Site 606: sequential events of $\delta^{18} \mathrm{O}$ enrichment beginning at 3.1 Ma. In Ruddiman, W. F., Kidd, R. B., Thomas, E., et al., Init. Repts. DSDP, 94 (Pt. 2): Washington (U.S. Govt. Printing Office), 911-920.

1987. Toward a high-resolution chronology for latest Miocene paleoceanographic events. Paleoceanography, 2:639-660.

Keigwin, L. D., and Corliss, B. H., 1986. Stable isotopes in late middle Eocene to Oligocene forams. Geol. Soc. Am. Bull., 97:335-345.

Keigwin, L. D., and Keller, G., 1984. Middle Oligocene climate change from equatorial Pacific Site 77. Geology, 12:16-19.

Keller, G., and Barron, J. A., 1983. Paleoceanographic implications of Miocene deep-sea hiatuses. Geol. Soc. Am. Bull., 94:590-613.

Kemp, E. M., and Barrett, P. J., 1975. Palynology of Leg 28 drill sites, Deep Sea Drilling Project. In Hayes, D. E., Frakes, L. A., et al., Init. Repts. DSDP, 28: Washington (U.S. Govt. Printing Office), 599-621.

Kennett, J. P., 1977. Cenozoic evolution of Antarctic glaciation, the circum-Antarctic Ocean, and their impact on global paleoceanography. J. Geophys. Res., 82:3843-3860.

1978. The development of planktonic biogeography in the Southern Ocean during the Cenozoic. Mar. Micropaleontol., 3:301345 .

1980. Paleoceanographic and biogeographic evolution of the Southern Ocean during the Cenozoic and Cenozoic microfossil datums. Palaeogeogr., Palaeoclimatol., Palaeoecol., 31:123-152.

1986. Miocene to early Pliocene oxygen and carbon isotope stratigraphy of the Southwest Pacific, DSDP Leg 90. In Kennett, J. P., von der Borch, C. C., et al., Init. Repts. DSDP, 90 (Pt. 2): Washington (U.S. Govt. Printing Office), 1383-1411.

Kennett, J. P., and Barker, P. F., 1990. Latest Cretaceous to Cenozoic climate and oceanographic developments in the Weddell Sea, Antarctica: an ocean-drilling perspective. In Barker, P. F., Kennett, J. P., et al., Proc. ODP, Sci. Results, 113: College Station, TX (Ocean Drilling Program), 937-960.

Kennett, J. P., Burns, R. E., Andrews, J. E., Churkin, M., Jr., Davies, T. A., Dumitrica, P., Edwards, A. R., Galehouse, J. S., Packham, G. H., and van der Lingen, G. J., 1972. Australian-Antarctic continental drift, paleo-circulation change and Oligocene deep-sea erosion. Nature, 239:51-55.

Kennett, J. P., Houtz, R. E., Andrews, P. B., Edwards, A. E., Gostin, V. A., Hajos, M., Hampton, M., Jenkins, D. G., Margolis, S. V., Ovenshine, A. T., and Perch-Nielsen, K., 1975. Cenozoic paleoceanography in the southwest Pacific Ocean, Antarctic glaciation, and the development of the Circum-Antarctic Current. In Kennett, J. P., Houtz, R. E., et al., Init. Repts. DSDP, 29: Washington (U.S. Govt. Printing Office), 1155-1169.
Kennett, J. P., and Stott, L. D., 1990. Proteus and proto-oceanus: ancestral paleogene oceans as revealed from Antarctic stable isotopic results: ODP Leg 113. In Barker, P. F., Kennett, J. P., et al., Proc. ODP, Sci. Results, 113: College Station, TX (Ocean Drilling Program), 865-880.

Ledbetter, M. T., and Ciesielski, P. F., 1986. Post-Miocene disconformities and paleoceanography in the Atlantic sector of the Southern Ocean. Palaeogeogr., Palaeoclimatol., Palaeoecol., 52:185-214.

Lisitzin, A. P., 1972. Sedimentation in the World Ocean, with Emphasis on the Nature, Distribution and Behavior of Marine Suspensions. Soc. Econ. Paleontol. Mineral Spec. Publ., 17.

Loutit, T. S., and Kennett, J. P., 1981. Australasian Cenozoic sedimentary cycles, global sea level changes and the deep-sea sedimentary record. Oceanol. Acta, Spec. Publ.:45-63.

Margolis, S. V., and Kennett, J. P., 1971. Cenozoic paleoglacial history of Antarctica recorded in subantarctic deep-sea cores. Am. J. Sci., 271:1-36.

Matthews, R. K., and Poore, R. Z., 1980. Tertiary $\delta^{18} \mathrm{O}$ record and glacio-eustatic sea-level fluctuations. Geology, 8:501-504.

McKelvey, B. C., and Stephenson, N.C.N., 1990. A geological reconnaissance of the Radok Lake area, Amery Oasis, Prince Charles Mountains. Antarct. Sci., 2:53-66.

Mildenhall, D. C., 1989. Terrestrial palynology. In Barrett, P. J. (Ed.), Antarctic Cenozoic History from the CIROS-1 Drillhole, McMurdo Sound: DSIR Bull., 245:119-127.

Miller, K. G., Fairbanks, R. G., and Mountain, G. S., 1987. Tertiary oxygen isotope synthesis, sea-level history, and continental margin erosion. Paleoceanography, 2:1-19.

Miller, K. G., Feigenson, M. D., and Wright, J. D., in press. Miocene isotope standard sections, DSDP Site 608: an evaluation of isotope and biostratigraphic resolution. Paleoceanography.

Moore, T. C., Jr., van Andel, T. H., Sancetta, C., and Pisias, N., 1978. Cenozoic hiatuses in the pelagic sediments. Micropaleontology, 24: 113-138.

Morley, J. J., 1989. Radiolarian-based transfer functions for estimating paleoceanographic conditions in the Southern Indian Ocean. Mar. Micropaleontol., 13:293-307.

Murphy, M. G., and Kennett, J. P., 1986. Development of latitudinal thermal gradients during the Oligocene: oxygen-isotope evidence from the southwest Pacific. In Kennett, J. P., von der Borch, C. C., et al., Init. Repts. DSDP, 90: Washington (U.S. Govt. Printing Office), $1347-1360$.

Nelson, C. H., and Nilsen, T. H., 1984. Modern and ancient deep-sea fans. SEPM Short Course, 14

Oberhansli, H., McKenzie, J. A., Toumarkine, M., and Weissert, H., 1984. A paleoclimatic and paleoceanographic record of the Paleogene in the central South Atlantic (Leg 73, Sites 522, 523, and 524). In Hsü, K. J., LaBrecque, J. L., et al., Init. Repts. DSDP, 73: Washington (U.S. Govt. Printing Office), 737-747.

Oerlemanns, J., 1982. A model of the Antarctic ice sheet. Nature, 297: 550-553.

Osborn, N. I., Ciesielski, P. F., and Ledbetter, M. T., 1983. Disconformities and paleoceanography in the southeast Indian Ocean during the past 5.4 million years. Geol. Soc. Am. Bull., 94:1345-1358.

Pickard, J. (Ed.), 1986. Antarctic Oasis. Terrestrial Environments and History of the Vestfold Hills, East Antarctica: Sydney (Academic Press).

Pickard, J., Adamson, D. A., Harwood, D. M., Miller, G. H., Quilty, P. G., and Dell, R. K., 1988. Early Pliocene marine sediments, coastline, and climate of East Antarctica. Geology, 16:158-161.

Prentice, M. L., and Matthews, R. K., 1988. Cenozoic ice-volume history: development of a composite oxygen isotope record. Geology, 17:963-966.

Raymo, M. E., Ruddiman, W. F., Backman, J., Clement, B. M., and Martinson, D. G., 1989. Late Pliocene variation in Northern Hemisphere ice sheets and North Atlantic deep water circulation. Paleoceanography, 4:413-446.

Robin, G. de Q., 1988. The Antarctic ice sheet, its history and response to sea level and climatic changes over the past 100 million years. Palaeogeogr., Palaeoclimatol., Palaeoecol., 67:31-50.

Rust, B. R., and Koster, E. H., 1984. Coarse alluvial deposits. In Walker, R. G. (Ed.), Facies Models (2nd ed.): Geosci. Can. Reprint Ser., 1:53-69. 
Sarnthein, M., and Tiedemann, R., 1989. Toward a high-resolution stable isotope stratigraphy of the last 3.4 million years: Sites 658 and 659 off northwest Africa. In Ruddiman, W., Sarnthein, M., et al., Proc. ODP, Sci. Results, 108: College Station, TX (Ocean Drilling Program), 167-185.

Schlich, R., Wise, S. W., Jr., et al., 1989. Proc. ODP, Init. Repts., 120: College Station, TX (Ocean Drilling Program).

Shackleton, N. J., 1986. Paleogene stable isotope events. Palaeogeogr., Palaeoclimatol., Palaeoecol., 57:91-102.

Shackleton, N. J., and Kennett, J. P., 1975. Paleotemperature history of the Cenozoic and the initiation of Antarctic glaciation: oxygen and carbon isotope analyses in DSDP Sites 277, 279 and 281. In Kennett, J. P., Houtz, R. E., et al., Init. Repts. DSDP, 29: Washington (U.S. Govt. Printing Office), 743-755.

Stagg, H.M.J., 1985. The structure and origin of Prydz Bay and MacRobertson Shelf, East Antarctica. Tectonophysics, 114:315-340.

Thomas, R. H., 1979. The dynamics of marine ice sheets. J. Glaciol., 24:167-177.

Tucholke, B. E., Hollister, C. D., Weaver, F. M., and Vennum, W. R., 1976. Continental rise and abyssal plain sedimentation in the southeast Pacific basin, Leg 35. In Hollister, C. D., Craddock, C., et al., Init. Repts. DSDP, 35: Washington (U.S. Govt. Printing Office), 359-400.

Vail, P. R., and Hardenbol, J., 1979. Sea-level changes during the Tertiary. Oceanus, 22:71-79.

Vail, P. R., Mitchum, R. M., Jr., Todd, R. G., Widmier, J. M., Thompson, S. III, Sangree, J. B., Bubb, J. N., and Hatlelid, W. G., 1977. Seismic stratigraphy and global changes in sea level. In Payton, C. E. (Ed.), Seismic Stratigraphy-Applications to Hydrocarbon Exploration: AAPG. Mem., 26:49-212.
Webb, P.-N., 1990. Review: the Cenozoic history of Antarctica and its global impact. Antarctic Sci., 2:3-21.

, in press. A review of the Cenozoic stratigraphy and paleontology of Antarctica. In Thomson, M.R.A. (Ed.), Proc. 5th Int. Conf. Antarctic Geology and Geophysics: Cambridge, UK (Cambridge Univ. Press).

Webb, P. N., Harwood, D. M., McKelvey, B. C., Mercer, J. N., and Stott, L. D., 1984. Cenozoic marine sedimentation and ice-volume variation on the East Antarctic craton. Geology, 12:287-291.

Wei, W., in press. Calcareous nannofossil stratigraphy and reassessment of the Eocene glacial record in subantarctic piston cores of the southeast Pacific. In Schlich, R., Wise, S. W., Jr., et al., Proc. ODP, Sci. Results, 120: College Station, TX (Ocean Drilling Program).

Wise, S. W., Gombos, A. M., and Muza, J. P., 1985. Cenozoic evolution of polar water masses, southwest Atlantic Ocean. In Hsü, K. J., and Weissert, H. J. (Eds.), South Atlantic Paleoceanography: Cambridge (Cambridge Univ. Press), 283-324.

Wise, S. W., Jr., Breza, J. R., Harwood, D. M., and Wei, W., in press. Paleogene glacial history of Antarctica. In Müller, D. W., MacKenzie, J. A., and Weissert, H. (Eds.), Controversies in Modern Geology: New York (Academic Press).

Zinsmeister, W. J., 1982. Late Cretaceous-Early Tertiary molluscan biogeography of the southern circum-Pacific. J. Paleontol., 56:84102.

Date of initial receipt: 22 May 1990

Date of acceptance: 8 August 1990

Ms 119B-194 